\title{
The anticancer effect related to disturbances in redox balance on Caco- 2 cells caused by an alkynyl gold(I) complex
}

\author{
Cristina Sánchez-de-Diego ${ }^{a}$, Inés Mármol ${ }^{\mathrm{a}}$, Rocío Pérez ${ }^{\mathrm{a}}$, Sonia Gascón ${ }^{\mathrm{a}}, \mathrm{M}^{\mathrm{a}}$ Jesús Rodriguez-Yoldi $^{\mathrm{a}}$ *, \\ Elena Cerrada ${ }^{\mathrm{b}, *}$ \\ a Departamento de Farmacología y Fisiología. Unidad de Fisiología, Facultad de Veterinaria, Universidad de Zaragoza, 50013, Zaragoza, CIBERobn, Spain \\ ${ }^{\mathrm{b}}$ Departamento de Química Inorgánica, Instituto de Síntesis Química y Catálisis Homogénea-ISQCH, Universidad de Zaragoza-C.S.I.C., 50009 Zaragoza, Spain
}

\section{A R T I C L E INFO}

Article history:

Received 16 September 2016

Received in revised form 17 October 2016

Accepted 3 November 2016

Available online $\mathrm{xxx}$

Keywords:

Apoptosis

Alkynyl gold(I)

Thioredoxin reductase

Redox

Cytochrome $c$

Caco-2 cells

\section{Introduction}

Colorectal adenocarcinoma is one of the main causes of cancer-related death and the second most prevalent carcinoma in Western countries. The overall five-year survival is only $40 \%$ and further its incidence rates are increasing in many countries [1,2]. Treatment involves surgical resection followed by 5 -fluoracil-based adjuvant therapy, but although it substantially improves survival, it is associated with side effects that affect overall health and quality of life [3-5]. Therefore it is necessary to develop a novel, less toxic and more efficient therapy to treat colorectal cancer (CRC).

Most of chemotherapeutic agents are organic molecules, but after discovering antiproliferative properties of cisplatin (cis-diamminedichloroplatinum(II)) [6,7], other derivatives known as second- and third-generation analogs to cisplatin are being used in a variety of cancers [8]. Despite the effectiveness of these platinum based drugs in cancer chemotherapy, there are some drawbacks such as the development of resistant tumour lines, long term-effects on renal function and lack of specificity [9]. This fact encourages researches to find alternatives in order to minimize these negative side-effects. Thus, a vast library of metal complexes have been synthesized and analyzed as anticancer agents, being the noble metals group, the most studied [10-15]. In this context, gold-derivate drugs have recently

\footnotetext{
* Corresponding authors.

Email addresses: mjrodyol@unizar.es (M.J. Rodriguez-Yoldi); ecerrada@unizar. es (E. Cerrada)
}

emerged as new chemotherapeutic agents. Gold compounds have been already used in medicine as antibacterial drugs, but nowadays they are in focus thanks to the strong cytotoxicity triggered by the gold atom in the oxidation states +1 and +3 in different cancer cell lines [16-21]. Two key points make gold compounds an interesting alternative to cisplatin and its analogs: their similar chemical behavior (both platinum(II) and gold(III) present electron configuration $\mathrm{d}^{8}$ and square planar geometry) and its wide coordination chemistry, which allows the synthesis of many different anticancer drugs.

Over the last decades, different types of gold-based drugs have been reviewed in order to determinate an appropriate ligand/compound combination with improved hydrophilic/lipophilic balance, optimized biodistribution, activity and selectivity to be chosen as a potential drug in colon cancer treatment. With this idea, the use of water-soluble phospanes like PTA (1,3,5-triaza-7-phosphaadamantane) could improve those properties and lead to the synthesis of water soluble or partially soluble complexes [22-28].

Nevertheless, despite all the investigation in gold-based drugs published in the last years, their mechanism of action remains unclear [29]. Gold compounds in oxidation state +1 are classified as "soft Lewis acids" and hence it is thought that they might target, strongly and selectively, thiol and selenol groups of proteins [30], which are critical to maintain the correct function of reductase proteins involved in redox balance. This is the particular cases of glutathione system $(\mathrm{GSH})$ and thioredoxin system, which are two of the four most important antioxidant systems in most cells. The thioredoxin system, constituted by thioredoxin (Trx), thioredoxin reductase (TrxR) and $\mathrm{NADPH}$, regulates crucial functions such as viability, proliferation 
and the level of cellular hydrogen peroxide [31]. It is thought that the selenocystein contained in Thioredoxin Reductase 1 (TrxR1) could constitute a target for gold-based drugs [32].

Thioredoxin Reductase 1 (TrxR1) (EC:1.8.1.9), the cytosolic form of TrxR, is an homodimeric protein codified by the gene TXNRD1. Seven isoforms of TXNRD1 gene have been described, being isoform 1 the canonical sequence, which is mainly expressed in ovary, spleen, heart, liver, kidney and pancreas, as well as cancer cells. The active form of the enzyme contains one selenocysteine and one FAD (Flavin Adenine Dinucleotide) group per subunit of $55 \mathrm{kDa}$ and it holds glutarredoxin and thioredoxin activity in association with Thioredoxin protein. Both proteins contribute to redox homeostasis, preventing and repairing damage caused by $\mathrm{H}_{2} \mathrm{O}_{2}$-based oxidative stress. TrxR 1 also induces the actine and tubulin polymerization. As a consequence of redox imbalance in tumour cells, Thioredoxin and Thioredoxin Reductase expression resulted increased in several human primary cancers and its levels are associated with aggressive tumour growth and decreased patient survival [33]. Moreover, inhibition of TrxR1 with siRNA in lung cancer cells reverses their tumour morphology and growth properties returning them to a state with similar properties than normal cells [34]. Furthermore, TrxR1 contains a very accessible selenocysteine on its flexible C-terminal arm which can be modified - selectively and irreversibly - by electrophilic compounds, inactivating the enzyme. In consequence, TrxR1 became an attractive new target for cancer treatments. In particular, soft metal ions such as platinum(II) and gold(I), can coordinate to the selenocystein residue, acting as enzyme inhibitors, as has been previously observed in cisplatin [35] and in auranofin [(1-thio- $\beta$-D-glucopyranose-2,3,4,6-tetraacetato-S)(triethylphosphane) gold] [36].

The preliminary good cytotoxic properties found in alkynyl gold(I) derivatives against A2780 ovarian cancer cells and their cisplatin-resistant cell line A2780cisR [25] encouraged us to extend and deepen antiproliferative studies in the particular case of $[\mathrm{Au}(\mathrm{C} \equiv$ $\mathrm{CPh})(\mathrm{PTA})]$. Thus, here we include the evaluation of the cytotoxic activity of the gold compound towards human colon cancer cell line Caco-2/TC7, the capacity of this complex to induce apoptosis, since apoptosis is the predominant mechanism by which cancer cells die, its implications in cell-cycle progression and its interactions with BSA, nucleic acids in order to discover its mechanism of action. Finally we include the influence of the gold(I) in the activity and expression of two important enzymes for redox balance: TXNDR1 and GR, as well as ROS formation. The results of this study suggest that $[\mathrm{Au}(\mathrm{C} \equiv$ $\mathrm{CPh})(\mathrm{PTA})]$ could be used as a therapeutic approach in colorectal cancer treatment.

\section{Experimental}

\subsection{Preparation of $[A u(C \equiv C P h)(P T A)]$}

$[\mathrm{Au}(\mathrm{C} \equiv \mathrm{CPh})(\mathrm{PTA})]$ was synthetized as described previously by some of us [25]. Briefly, phenylacetylene $(0.3 \mathrm{mmol})$ were added to a solution $\mathrm{KOH}(0.385 \mathrm{mmol})$ in $\mathrm{MeOH}$. After $10 \mathrm{~min}$ of stirring $[\mathrm{AuCl}(\mathrm{PTA})](0.25 \mathrm{mmol})$ was added. Then, the mixture was stirred for $c a .20 \mathrm{~h}$ at room temperature; the precipitate was isolated by filtration, washed twice with $\mathrm{MeOH}$ and dried with diethyl ether. Yellow solid was obtained in $83 \%$ yield. ${ }^{1} \mathrm{H}$ NMR $(400 \mathrm{MHz}$, $\left.\mathrm{CDCl}_{3}, 25^{\circ} \mathrm{C}\right): \delta 4.28\left(\mathrm{~s}, 6 \mathrm{H}, \mathrm{NCH}_{2} \mathrm{P}\right), 4.48,4.53\left(J_{A B}=13.3 \mathrm{~Hz}, 6 \mathrm{H}\right.$, $\left.\mathrm{NCH}_{2} \mathrm{~N}\right), 7.20-7.31(\mathrm{~m}, 3 \mathrm{H}, m-$ and $p-\mathrm{Ph}), 7.43-7.50(\mathrm{~m}, 2 \mathrm{H}, o-\mathrm{Ph})$ ppm. ${ }^{31} \mathrm{P}\left\{{ }^{1} \mathrm{H}\right\} \operatorname{NMR}\left(\mathrm{CDCl}_{3}, 25^{\circ} \mathrm{C}\right): \delta-51.5 \mathrm{ppm} .{ }^{13} \mathrm{C}\left\{{ }^{1} \mathrm{H}\right\} \mathrm{NMR}$ $\left(\mathrm{CDCl}_{3}, 25^{\circ} \mathrm{C}\right): \delta 52.4\left(\mathrm{~d}, 3 \mathrm{C}, J=21.6 \mathrm{~Hz}, \mathrm{NCH}_{2} \mathrm{P}\right), 63.8(\mathrm{~s}, 1 \mathrm{C}$, $\mathrm{AuC} \equiv \mathrm{C}), 73.3\left(\mathrm{~d}, J=7.8 \mathrm{~Hz}, 3 \mathrm{C}, \mathrm{NCH}_{2} \mathrm{~N}\right), 82.7(\mathrm{~s}, 1 \mathrm{C}, \mathrm{AuC} \equiv$ C), $127.30(\mathrm{~s}, 1 \mathrm{C}, p-\mathrm{Ph}), 128.51(\mathrm{~s}, 2 \mathrm{C}, o-\mathrm{Ph}), 132.4(\mathrm{~s}, 4 \mathrm{C}, m-\mathrm{Ph})$ ppm. Anal. Calcd. (\%) for $\mathrm{C}_{14} \mathrm{H}_{17} \mathrm{AuN}_{3} \mathrm{P}$ (455.25): C 36.94, H3.76, N 9.23. Found: C 36.56, H3.39, N 9.09.

\subsection{Chemical stability}

The stability of the gold complex has been analyzed by absorption UV spectroscopy. UV-Vis absorption spectra were recorded on a Thermo Scientific spectrophotometer. $20 \mathrm{mM}$ solution of $[\mathrm{Au}(\mathrm{C} \equiv$ $\mathrm{CPh}$ (PTA)] in DMSO (Dimethyl sulfoxide) was diluted in $10^{-4} \mathrm{M}$ $\mathrm{PBS} \mathrm{pH}=7.4$ and thereafter monitored measuring the electronic spectra over $24 \mathrm{~h}$ at $37^{\circ} \mathrm{C}$.

\subsection{Distribution coefficient $\left(\log D_{7.4}\right)$}

N-octanol-water partition coefficient was determined by the shake-flask method. PBS buffered distilled water $(100 \mathrm{~mL}$, phosphate buffer $\left.\left[\mathrm{PO}_{4}{ }^{3-}\right]=10 \mu \mathrm{M}, 0.15 \mathrm{M} \mathrm{NaCl}, \mathrm{pH} 7.4\right)$ and $100 \mathrm{~mL}$ of $\mathrm{n}$-octanol shaken together for $72 \mathrm{~h}$ to allow saturation of both phases. Approximately $1 \mathrm{mg}$ of the complex was mixed in $5 \mathrm{~mL}$ of aqueous and organic phase, respectively for $10 \mathrm{~min}$. The resultant emulsion was centrifuged to separate the phases. The concentration of the compound in each phase was determined using UV absorbance spectroscopy. $\log D_{7.4}$ was defined as $\log \left\{\left[\operatorname{compound}_{\text {(organic) }}\right] /\left[\operatorname{compound}_{(\text {aqueous })}\right]\right\}$.

\subsection{Interaction with $B S A$}

Bovine serum albumine was commercially available from Sigma Aldrich. $A 1 \mathrm{mM}$ stock solution of BSA was prepared in PBS at $\mathrm{pH}$ 7.4. The real concentration is confirmed using UV-Vis spectroscopy $\left(\varepsilon_{280 \mathrm{~nm}}=43,824 \mathrm{M}^{-1} \mathrm{~cm}^{-1}\right)$. The gold complex was dissolved in dimethyl sulfoxide (DMSO) to achieve $6 \mathrm{mM}$ stock solution and six aliquots of $2.5 \mu \mathrm{L}$ were added to a $50 \mu \mathrm{M}$ solution of BSA in PBS placed in a quartz cuvette of $1 \mathrm{~cm}$ optical path, giving rise to final concentrations of $5,10,15,20,25$ and $30 \mu \mathrm{M}$. The fluorescence spectra were recorded on a Jobin-Yvon-Horiba fluorolog FL-3-11 spectrometer. The samples were excited at $295 \mathrm{~nm}$ and the emission spectra were recorded in a range from 310 to $450 \mathrm{~nm}$ with emission slits set to $1.6 \mathrm{~nm}$. The samples were measure $4 \mathrm{~min}$. After every addition of the aliquots of gold complex. The fluorescence intensities of the PBS and the gold complex were irrelevant under the described conditions, as were the effect of addition of gold aliquots and the effect of time incubation between measurements. The data were analyzed using the Stern-Volmer equation $\mathrm{F}_{0} / \mathrm{F}=1+\mathrm{K}_{\mathrm{sv}}$ [gold complex] $=1+\mathrm{K}_{\mathrm{q}} \tau_{0}$ [gold complex] in order to obtain the Stern-Volmer quenching constant $\left(\mathrm{K}_{\mathrm{sv}}\right)$. The binding constant $\left(\mathrm{K}_{\mathrm{b}}\right)$ was quantified by using the modified Stern-Volmer equation: $\log \left\{\left(\mathrm{F}_{0}-\mathrm{F}\right) / \mathrm{F}\right\}=\log K_{b}+n \log$ [gold complex].

\subsection{Cell culture}

Human Caco-2 cell line (TC7 clone) was kindly provided by Dr. Edith Brot-Laroche (Université Pierre et Marie Curie-Paris 6, UMR S 872, Les Cordeliers (France). Caco-2 cells were maintained in a humidified atmosphere of $5 \% \mathrm{CO}_{2}$ at $37^{\circ} \mathrm{C}$. Cells (passages $50-80$ ) were grown in Dulbecco's Modified Eagles medium (DMEM) (Gibco Invitrogen, Paisley, UK) supplemented with $20 \%$ fetal bovine serum (FBS), 1\% non-essential amino acids, $1 \%$ penicillin $(1000 \mathrm{U} / \mathrm{mL}), 1 \%$ streptomycin $(1000 \mu \mathrm{g} / \mathrm{mL})$ and $1 \%$ amphoterycin $(250 \mathrm{U} / \mathrm{mL})$. The cells were passaged enzymatically with $0.25 \%$ trypsin- 1 mM EDTA and sub-cultured on 25 or $75 \mathrm{~cm}^{2}$ plastic flasks at a density of $2 \times 10^{4}$ cells $/ \mathrm{cm}^{2}$. Culture medium was replaced every 2 days. Cell confluence $(80 \%)$, differentiated cells, was confirmed by microscopic 
observance. Experiments in undifferentiated cells were performed 24 days post-seeding.

\subsection{Cell proliferation assay and $I C_{50}$ values determination}

Cell proliferation inhibition was measured using the MTT assay [37]. The assay is dependent on the cellular reduction of 3-(4,5-dimethyl-2-thiazoyl)-2,5-diphenyltetrazolium bromide (MTT, Merck, Darmstadt Germany) by the mitochondrial dehydrogenase of viable cells to a blue formazan product which can be measured spectrophotometrically. Caco-2/TC7 cells were plated in 96-well plates at a density of 4000 cells per well and incubated for $24 \mathrm{~h}$ under standard cell culture conditions.

For $\mathrm{IC}_{50}$ values determination, a stock solution of the gold complex in DMSO was added to cells in a concentration range of $0-20 \mu \mathrm{M}$ (10 replicates, $100 \mu \mathrm{L}$ per well); cells treated with the same amount of DMSO were used as negative control. Cells were exposed to the gold complex for $24 \mathrm{~h}$ and then $10 \mu \mathrm{L}$ of $5 \mathrm{mg} / \mathrm{mL}$ MTT solution were added. Incubation was continued at $37^{\circ} \mathrm{C}$ for $3 \mathrm{H}$. medium was then removed by inversion and $100 \mu \mathrm{L}$ of DMSO per well were added. The solution absorbance at $560 \mathrm{~nm}$, proportional to number of living cells, was measured by spectrophotometry (DTX 800, Beckman Coulter) and converted into percentage (\%) of growth inhibition.

\subsection{Propidium iodide staining of DNA content and cell cycle analysis}

Caco-2/TC7 cells were exposed to $\mathrm{IC}_{50}$ of the $[\mathrm{Au}(\mathrm{C} \equiv$ $\mathrm{CPh})(\mathrm{PTA})]$ for $24 \mathrm{~h}$. Then, cells were fixed in $70 \%$ ice-cold ethanol and stored at $4{ }^{\circ} \mathrm{C}$ for $24 \mathrm{~h}$ and centrifuged $5 \mathrm{~min}$ at $2500 \mathrm{rpm}$. After centrifugation, cells were rehydrated in phosphate buffered saline (PBS) and stained with $50 \mu \mathrm{g} / \mathrm{mL}$ propidium iodide (PI) solution containing $100 \mu \mathrm{g} / \mathrm{mL}$ RNase A. PI-stained cells were analyzed for DNA content in a FACSARRAY BD equipped with an argon ion laser. The red fluorescence emitted by PI was collected using a $620 \mathrm{~nm}$ long pass filter as a measure of the amount of DNA-bound PI and cell distribution was displayed on a linear scale. Cell cycle distribution was determined on a linear scale. The percentage of cells in cycle phases was determined using MODIFIT 3.0 verity software.

\subsection{Measurements of apoptosis}

Caco-2/TC7 cells were exposed to $\mathrm{IC}_{50}$ of the $[\mathrm{Au}(\mathrm{C} \equiv$ $\mathrm{CPh})(\mathrm{PTA})]$ for $24 \mathrm{~h}$, then collected and stained with Annexin V-FTIC according to the manufacturer's instructions. Untreated cells were used as negative control, in order to define basal levels of apoptosis, necrosis and cell death. After incubation, cells were transferred to flow-cytometry tubes and washed twice with temperate phosphate-buffered saline (PBS), resuspended in $100 \mu \mathrm{L}$ of annexin V binding buffer (10 mM Hepes/NaOH, pH 7.4, $140 \mathrm{mM} \mathrm{NaCl}, 2.5 \mathrm{mM}$ $\mathrm{CaCl}_{2}$ ), then $5 \mu \mathrm{L}$ of annexinV-FITC and $5 \mu \mathrm{L}$ of PI was added to each $100 \mu \mathrm{L}$ of cell suspension. After incubation for $15 \mathrm{~min}$ at room temperature in the dark, $400 \mu \mathrm{L}$ of $1 \times$ annexin binding buffer was added and analyzed by flow cytometry within one hour. The signal intensity was measured using a FACSARIA BD and analyzed using FASCDIVA BD.

\subsection{In vitro DNA binding assay}

$[\mathrm{Au}(\mathrm{C} \equiv \mathrm{CPh})(\mathrm{PTA})]$ was incubated at $37^{\circ} \mathrm{C}$ with $3 \mathrm{nM}$ pIRES2-EGFP (5308 pb) plasmid (Catalog \#6029-1). The mobility of pIRES2-EGFP treated with the complex was analyzed by electrophoresis on a $1 \%(w / v)$ agarose gel at $90 \mathrm{~V} / \mathrm{cm}$ at $25^{\circ} \mathrm{C}$ in Tris-ac-
etate/EDTA buffer for $30 \mathrm{~min}$. The gel was stained in $0.5 \mathrm{~g} / \mathrm{mL}(w / v)$ ethidium bromide and bands were visualized with UVP gel scanner.

\subsection{DNA isolation}

Caco-2/TC7 cells were plated in $75 \mathrm{~cm}^{2}$ flask at a density of 500,000 cells per flask, incubated for $24 \mathrm{~h}$ under standard cell culture conditions and then exposed to $\mathrm{IC}_{50}$ of the $[\mathrm{Au}(\mathrm{C} \equiv \mathrm{CPh})(\mathrm{PTA})]$ for $24 \mathrm{~h}$. Cells were centrifuged at $3500 \mathrm{rpm}$ for $5 \mathrm{~min}$ and pellet was washed twice with $1 \mathrm{~mL}$ PBS. Then cells were lysated using $1 \mathrm{~mL}$ lysis buffer $(5 \mathrm{M} \mathrm{NaCl}, 1 \mathrm{M}$ Tris-HCl pH 8, $0.5 \mathrm{M}$ EDTA pH 8, 10\% SDS, miliQ water, $20 \mu \mathrm{L}$ proteinase $\mathrm{K}$ ). Resultant preparation was incubated $19 \mathrm{~h}$ at $50-60^{\circ} \mathrm{C}$. $250 \mu \mathrm{L}$ of $5 \mathrm{M} \mathrm{NaCl}$ were added and the mixture was centrifuged at $13,000 \mathrm{rpm}$ for $5 \mathrm{~min}$. Supernatant was isolated and $2 \mathrm{~mL}$ of ethanol $100 \%$ were added, then samples were centrifuged at 10,000 rpm for $10 \mathrm{~min}$. Pellet was washed with $1.5 \mathrm{~mL}$ of ethanol $70 \%$ and centrifuged at $10,000 \mathrm{rpm}$ for $10 \mathrm{~min}$. Finally, the pellet was resuspended in $50 \mu \mathrm{L}$ Tris-EDTA pH 8 (TE) and heated to $40{ }^{\circ} \mathrm{C}$ for $5 \mathrm{~min}$.

\subsection{DNA interaction in cells}

DNA of $[\mathrm{Au}(\mathrm{C} \equiv \mathrm{CPh})(\mathrm{PTA})]$ treated cells was isolated as previously described. Then, DNA interactions were analyzed by SDS-PAGE using $2 \%(w / v)$ agarose gel containing $100 \mu \mathrm{g} / \mathrm{mL}$ of ethidium bromide $(85 \mathrm{~V}, 45 \mathrm{~min})$.

\subsection{RNA isolation}

Caco-2/TC7 cells were plated in $75 \mathrm{~cm}^{2}$ flask at a density of 500,000 cells per flask, incubated for $24 \mathrm{~h}$ under standard cell culture conditions and then exposed to $\mathrm{IC}_{50}$ of the $[\mathrm{Au}(\mathrm{C} \equiv \mathrm{CPh})(\mathrm{PTA})]$ for $24 \mathrm{~h}$. After that, $650 \mu \mathrm{L}$ of TRI Reagent ${ }^{\circledR}$ (SIGMA-ALDRICH® 9424) were added to each flask.

For RNA isolation, the obtained cell suspension with TRI Reagent ${ }^{\circledR}$ was incubated with $130 \mu \mathrm{L}$ of chloroform for $10 \mathrm{~min}$ at room temperature. After incubation, the mix was centrifuged at $13,000 \mathrm{rpm}$ for $10 \mathrm{~min}$. Upper phase was collected and incubated with $430 \mu \mathrm{L}$ of isopropanol for $10 \mathrm{~min}$ at room temperature. The mix was centrifuged again at $13,000 \mathrm{rpm}$ for $15 \mathrm{~min}$. The precipitate was washed with ethanol $75 \%$, and centrifuged at $13,000 \mathrm{rpm}$ for $5 \mathrm{~min}$. The obtained pellet was dried at room temperature and hydrated with $25 \mu \mathrm{L}$ of free-nuclease water for $2-3 \mathrm{~h}$. RNA purity was checked with polyacrylamide gel electrophoresis (SDS-PAGE) using $1 \%(w / v)$ agarose gel containing $100 \mu \mathrm{g} / \mathrm{mL}$ of ethidium bromide $(80 \mathrm{~V}, 1 \mathrm{~h})$.

\subsection{Flow cytometry mitochondrial membrane potential assay}

Caco-2/TC7 cells were plated in $75 \mathrm{~cm}^{2}$ flask at a density of 500,000 cells per flask and incubated $24 \mathrm{~h}$ under standard cell culture conditions. For treatment, $\mathrm{IC}_{50}$ of gold complex was added to each flask and incubated $24 \mathrm{~h}$; mock-treated cells were just incubated with DMSO at the same concentration than treated samples. After treatment, cells were washed twice with temperate PBS and then resuspended in temperate PBS at a concentration of $1 \times 10^{6}$ cells $/ \mathrm{mL} .5 \mu \mathrm{L}$ of $10 \mu \mathrm{M}$ cationic dye 1,1',3,3,3'-hexamethylindodicarbo-cyanine iodide (DiIC1) were added to each sample and cells were incubated $15 \mathrm{~min}$ at $37^{\circ} \mathrm{C}, 5 \% \mathrm{CO}_{2}$. After incubation period, $400 \mu \mathrm{L}$ of PBS were added to each tube and fluorescence was analyzed by flow cytometry using a FACSARRAY BD equipped with an argon ion laser. Excitation and emission settings were 633 and $658 \mathrm{~nm}$, respectively. 


\subsection{Determination of $B A X, B C L 2$, caspase-3, caspase-9 and TXNDR1 by flow cytometry}

Caco-2/TC7 cells were plated in $75 \mathrm{~cm}^{2}$ flask at a density of 500,000 cells per flask and incubated $24 \mathrm{~h}$ under standard cell culture conditions. For treatment, $\mathrm{IC}_{50}$ of gold complex was added to each flask and incubated $24 \mathrm{~h}$; mock-treated cells were just incubated with DMSO at the same concentration than treated samples. After treatment, cells were fixed in $0.01 \%$ formaldehyde for $15 \mathrm{~min}$ and centrifuged for $5 \mathrm{~min}$ at $300 \mathrm{~g}$ and room temperature (RT). Then, for cell membranes disruption, the pellet was suspended in $100 \mu \mathrm{L}$ of $0.5 \%$ $v / \mathrm{v}$ in PBS digitonin solution and incubated for $15 \mathrm{~min}$ in the dark at RT. After incubation, cells were washed with $2 \mathrm{~mL}$ of PBS containing $0.1 \%$ digitonin and centrifuged at $300 \mathrm{~g}$ for $5 \mathrm{~min}$. Supernatant was discarded and pellet was resuspended in $200 \mu \mathrm{L}$ of PBS containing $0.1 \%$ digitonin. The corresponding antibody $(2 \mu \mathrm{L})$ was added to each sample and the resultant mix was incubated for $1 \mathrm{~h}$ at RT. After incubation, cells were centrifuged $5 \mathrm{~min}$ at $500 \mathrm{~g}$ at RT and washed twice with PBS. Finally, cells were resuspended in $400 \mu \mathrm{L}$ of PBS. Fluorescence was analyzed by flow cytometry, using a FACSARRAY BD equipped with an argon ion laser. Antibodies used for these assays and the emission and excitation setting are listed above.

Anti-Bax antibody (Abcam [T22-A]) Ex: 493 nm, Em: 528 nm.

Anti-Bcl-2 antibody (Abcam) Ex: 645, Em 660,100 test.

Caspase 9 (active) Red Staining Kit (Ambcam) Ex: 394-400, Em: 495-505.

Anti-TXNRD1 antibody (Abcam, Alexa Fluor® 647) Ex: 652, Em: 668.

Anti-Caspase3 (Novus, Clone C92-605) Ex: 494, Em: 520.

\subsection{Determination of cytochrome c by flow cytometry}

Caco-2/TC7 cells were plated in $75 \mathrm{~cm}^{2}$ flask at a density of 500,000 cells per flask and incubated $24 \mathrm{~h}$ under standard cell culture conditions. For treatment, $\mathrm{IC}_{50}$ of gold complex was added to each bottle and incubated $24 \mathrm{~h}$; mock-treated cells were just incubated with DMSO at the same concentration than treated samples. After treatment, cytochrome $c$ release was determined as described by Christensen et al. [38]. Briefly, cells were resuspended in $100 \mu \mathrm{L}$ of ice-cold permeabilization buffer $(100 \mathrm{mM} \mathrm{KCl}, 50 \mu \mathrm{g} / \mathrm{mL}$ digitonin in PBS) and incubated for $5 \mathrm{~min}$. Then, $100 \mu \mathrm{L}$ of $4 \%$ paraformaldehyde in PBS were added to permeabilised cells and the mixture was centrifuged $5 \mathrm{~min}$ at $500 \mathrm{~g}$ at $4{ }^{\circ} \mathrm{C}$. Supernatant was removed and the pellet was resuspended in $4 \%$ paraformaldehyde and incubated $20 \mathrm{~min}$ at RT. After incubation, cells were washed three times in $200 \mu \mathrm{L}$ of PBS. The obtained pellet was resuspended in $200 \mu \mathrm{L}$ of permeabilization buffer $(0.05 \%$ Saponin, 3\% BSA in PBS) and incubated for $15 \mathrm{~min}$ at RT. Then, $2 \mu \mathrm{L}$ of anti-cytochrome antibody (Novus (7H8.2C12)[PE]) were added and the mix was incubated for $1 \mathrm{~h}$ at RT. After incubation, cells were centrifuged $5 \mathrm{~min}$ at $500 \mathrm{~g}$ at RT and washed twice with PBS. Finally, cells were resuspended in $400 \mu \mathrm{L}$ of PBS. Fluorescence was analyzed by flow cytometry using a FACSARRAY BD equipped with an argon ion laser. Excitation and emission settings were 488 and $575 \mathrm{~nm}$, respectively.

\subsection{Intracellular peroxides (ROS) formation}

The production of ROS (Reactive Oxygen Species) was assessed using the dichlorofluorescein (DCF) assay [39]. Caco-2/TC7 cells were plated in 96-well plates at a density of 4000 cells per well and incubated for $24 \mathrm{~h}$ under standard cell culture conditions. For treatment, $\mathrm{IC}_{50}$ of $[\mathrm{Au}(\mathrm{C} \equiv \mathrm{CPh})(\mathrm{PTA})]$ was added to cells and incubated
$24 \mathrm{~h}$; mock-treated cells were just incubated with DMSO at the same concentration than treated cells. Then, cells were washed twice with PBS and $100 \mu \mathrm{L}$ of $20 \mathrm{mM}$ DCFH-DA (dichloro-dihydro-fluoresceindiacetate) were added to each well. Cells were incubated $1 \mathrm{~h}$ at $37^{\circ} \mathrm{C}$ and washed twice with PBS; finally, $100 \mu \mathrm{L}$ of PBS were added and fluorescence was analyzed with DTX-880 (Beckman Counter). Excitation and emission settings were 485 and $535 \mathrm{~nm}$, respectively. The intensity of fluorescence is considered as a reflection of total intracellular ROS.

\subsection{Thiol-reductase activity assay in cells}

Caco-2 TC7 were grown in 96-well plate at a density of 4000 cells/well during $24 \mathrm{~h}$, and then treated with $[\mathrm{Au}(\mathrm{C} \equiv \mathrm{CPh})(\mathrm{PTA})]$ for $24 \mathrm{~h}$. After incubation time, cells were lysed with Tris- $\mathrm{HCl}$ buffer (5 M NaCl, 1 M Tris-HCl pH 8, 0.5 M EDTA pH 8, SDS 10\%, miliQ water) and proteinase $\mathrm{K}$ and $25 \mu \mathrm{L}$ of PBS pH 7.0 were added. Then, $25 \mu \mathrm{L}$ of reaction mix $(500 \mu \mathrm{L}$ PBS $\mathrm{pH} 7.4,7,80 \mu \mathrm{L} 100$ mM EDTA $\mathrm{pH} 7.5,20 \mu \mathrm{L}$ 0,05\% BSA, $20 \mathrm{mM} 100 \mu \mathrm{L} \mathrm{NADPH}, 300 \mu \mathrm{L}$ distilled $\mathrm{H}_{2} \mathrm{O}$ ) were add to each well. Finally, reaction was started by adding $25 \mu \mathrm{L}$ of $20 \mathrm{mM}$ 5,5-dithio-bis-(2-nitrobenzoic acid) (DTNB, in pure ethanol). Absorbance at $405 \mathrm{~nm}$ was recorded each $10 \mathrm{~s}$ for $6 \mathrm{~min}$ as a measure of thiol-reductase activity. Thiol-reductase activity was normalised by the amount of protein present in each well, determined by Bradford method.

\subsection{Glutathione reductase activity assay in cells}

Caco-2 TC7 were grown in 96-well plate at a density of 4000 cells/well during $24 \mathrm{~h}$, and then treated with $[\mathrm{Au}(\mathrm{C} \equiv \mathrm{CPh})(\mathrm{PTA})]$ for $24 \mathrm{~h}$. After incubation time, cells were lysed with modified RIPA buffer $(50 \mathrm{mM}$ Tris- $\mathrm{HCl}, 50 \mathrm{mM} \mathrm{NaCl}, 1 \mathrm{mM}$ EDTA, $1 \%$ Triton $\mathrm{X}-100,1 \% \mathrm{SDS}, 1 \%$ DOC, $1 \mathrm{mM} \mathrm{NaF}$, in miliQ water) with proteases inhibitors. Cell solution was shaken at RT for $20 \mathrm{~min}$, centrifuged for $5 \mathrm{~min}$ at $1200 \mathrm{rpm}$ and resuspended in PBS. Then, reaction solution was added (0.1 M Tris-HCl pH 8.1, 0.02 mM NADPH, in PBS). Finally, reaction was started by adding $0.52 \mathrm{mM}$ GSSG. Absorbance at $3340 \mathrm{~nm}$ was recorded for $6 \mathrm{~min}$. Glutathione Reductase Activity of the cell lysate was measured as a loss in absorbance at $340 \mathrm{~nm}$.

\subsection{Thioredoxin reductase 1 (TrxR1) activity assay in vitro}

Recombinant Human TrxR1 (SIGMA ${ }^{\circledR}$ SRP6081) was incubated in a 96 well plate with different concentrations of $[\mathrm{Au}(\mathrm{C} \equiv$ $\mathrm{CPh}$ (PTA)] complex previously dissolved in $25 \mu \mathrm{L}$ of $\mathrm{PBS}$ at $\mathrm{pH} 7.4$. The cell solution was incubated in shake motion for $75 \mathrm{~min}$ at $37^{\circ} \mathrm{C}$. After incubation time, $25 \mu \mathrm{L}$ of reaction mix $(500 \mu \mathrm{L}$ PBS $\mathrm{pH} 7$, $80 \mu \mathrm{L}, 100 \mathrm{mM}$ EDTA pH 7.5, $20 \mu \mathrm{L} 0.05 \%$ BSA, $100 \mu \mathrm{L} 20 \mathrm{mM}$ NADPH, $300 \mu \mathrm{L}$ distilled $\mathrm{H}_{2} \mathrm{O}$ ) were added to each well. Finally, reaction was started by adding $25 \mu \mathrm{L}$ of $20 \mathrm{mM}$ DNTB in pure ethanol. Absorbance at $405 \mathrm{~nm}$ was recorded each $10 \mathrm{~s}$ for 6 min as a measure of Thioredoxin Reductase Activity.

\subsection{TXNDRImRNA quantification}

TXNDRImRNAwas quantified by qRT-PCR.

$5 \mu \mathrm{g}$ of isolated RNA were cleaned up with the commercial kit Turbo DNA-free (Ambion AM1907). RNA integrity was analyzed after clean up by electrophoresis on a $1 \%(w / v)$ agarose gel at $90 \mathrm{~V} /$ $\mathrm{cm}$ at $25^{\circ} \mathrm{C}$ in Tris-acetate/EDTA buffer for $30 \mathrm{~min}$. The presence of protein and DNA contamination was checked in a NanodropTM 1000, (ThermoScientific). Cleaned RNA was retrotranscribed using 
the commercial kit ThermoScientific First Strand cDNA synthesis and $50 \mu \mathrm{M}$ Oligod(T $)_{20}$ primers. TXNDR1 mRNA quantification was performed by qRT-PCR using the reactive Fast Start SYBR Green Master Rox (Roche) and CXR. The primers used for qRT-PCR were 5'AAGGAACGCTCTCGGAATTG3' and 5'GATAAGCCTTCAAGGTTGGACC3'. Gene expression modification was quantified by $2-\Delta \Delta \mathrm{Ct}$, using cyclophiline B (PPIB) as housekeeping gene.

\section{Results and discussion}

\subsection{Solution chemistry}

$[\mathrm{Au}(\mathrm{C} \equiv \mathrm{CPh})(\mathrm{PTA})]$ was isolated as a pale yellow solid in good yield with high purity, confirmed by ${ }^{1} \mathrm{H}$ and ${ }^{31} \mathrm{P}$ NMR spectroscopy (Fig. S1) and no further purification was needed.

Chemical stability under physiological conditions constitutes a crucial characteristic of anti-tumour drugs used for treatment. Thus, the solution chemistry of the complex was studied by absorption UV-visible spectroscopy over $24 \mathrm{~h}$ at $37^{\circ} \mathrm{C}$. The complex exhibits intense bands between 200 and $300 \mathrm{~nm}$ attributed to electronic transitions from alkyne to gold(I) centre (Fig. S2). The intensity of these bands decreased over time, probably due to a reduction of the complex solubility. No additional bands were detected over the time and none around $500 \mathrm{~nm}$ indicative of colloidal gold( 0 ) formation. All these findings probe that $[\mathrm{Au}(\mathrm{C} \equiv \mathrm{CPh})(\mathrm{PTA})]$ is stable in $\mathrm{PBS}$ at $37^{\circ} \mathrm{C}$.

In addition to a solution stability, a balanced relationship between lipophilicity and hydrophilicity results important in drug delivery process. A potential drug should be transported in the body and pass through membrane channels and must diffuse through the lipid portion of the cell membrane. A high lipophilic character could cause an excessive accumulation of the compound inside the cells triggering severe toxic effects, as was previously evidenced in bis-phosphine gold(I) derivatives $[40,41]$. This relationship was measured in terms of $\log D_{7.4}$ (n-octanol/water partition coefficient under physiological conditions, pH 7.4). $\log D_{7.4}$ obtained for $[\mathrm{Au}(\mathrm{C} \equiv \mathrm{CPh})(\mathrm{PTA})]$ was 0.40 , revealing a slight lipophilic character of the complex.

\subsection{Interaction with $B S A$}

Serum albumins are one of the most studied molecules as model proteins in drug-protein interaction studies. In addition, they play an important role in the transport and deposition of the drugs to its targets $[42,43]$. Bovine serum albumin (BSA) is one of the most used proteins and presents $76 \%$ sequence identity with the human albumin (HSA) [44]. Most of drugs bond reversibly to serum albumin and then the drug-protein complex is transported through the blood stream. Moreover, the nature and force of this protein-drug interaction influence the biological activity of the drug and its pharmacodynamics. This interaction is especially important for lipophilic drugs as the gold complex under study $[\mathrm{Au}(\mathrm{C} \equiv \mathrm{CPh})(\mathrm{PTA})]$.

It has been demonstrated that binding to serum albumin can inhibit delivery and limit drug efficacy [45], and structural studies have identify the hydrophobic regions in serum albumin as the specific binding site [46]. In consequence, we decided to study the capacity of $[\mathrm{Au}(\mathrm{C} \equiv \mathrm{CPh})(\mathrm{PTA})]$ to interact with BSA and the nature of that binding. BSA comprises of a chain of 580 amino acids residues with a well-known structure consisting of a single peptide chain that contains two tryptophans, Trp-134 and Trp-212, which possess intrinsic fluorescence [47]. This amino acid is sensitive to its local environment, consequently any changes observed in its fluorescence emission spectra could indicate a possible conformational change or bind- ing to a substrate. The interaction of $[\mathrm{Au}(\mathrm{C} \equiv \mathrm{CPh})(\mathrm{PTA})]$ with BSA has been quantified by the measure of the fluorescence of BSA in the range of $310-450 \mathrm{~nm}$ upon excitation at $295 \mathrm{~nm}$ and in the presence of varying concentrations of the complex. As can be observed in Fig. 1, there is a decrease in the fluorescence intensity as a function of increasing concentration of the gold complex. The corresponding fluorescence quenching data were analyzed to obtain the quenching constant $K_{s v}$ by using the Stern-Volmer equation $\mathrm{F}_{0} / \mathrm{F}=1+K_{s v}$ [complex], where $\mathrm{F}_{0}$ and $\mathrm{F}$ are the fluorescence intensities at $350 \mathrm{~nm}$ in the absence and presence of $[\mathrm{Au}(\mathrm{C} \equiv \mathrm{CPh})(\mathrm{PTA})]$ (Table 1). After plotting $\mathrm{F}_{\mathrm{o}}$ versus [complex] the slope gives the value of $K_{s v}$ (Fig. $\left.2 \mathrm{~A}\right)$. We studied the interaction with BSA at different temperatures (see below) in order to elucidate the possible mechanism.

Determination of the binding constant in the case of interaction of small molecules with macromolecules can be afforded by the modified Stern-Volmer equation (double logarithm regression curve: $\log \left\{\left(\mathrm{F}_{0}\right.\right.$ $-\mathrm{F}) / \mathrm{F}\}=\log K_{b}+n \log [$ complex $\left.]\right)$. The equation gives the binding constant $\left(K_{b}\right)$ or the apparent association constant for complex-protein interaction and the number of binding sites $(n)$ (see Table 1). Both parameters can be deduced from the intercept and slope, respectively, by plotting $\log \left\{\left(\mathrm{F}_{0}-\mathrm{F}\right) / \mathrm{F}\right\}$ versus $\log [$ complex] (Fig. 2B). The value obtained in the experiment for the binding constant at room temperature of $7.21 \cdot 10^{4} \mathrm{M}^{-1}$ is notably higher than the measured in the interaction of cisplatin with HSA $8.52 \cdot 10^{2} \mathrm{M}^{-1}$ [48] and in related alkyne gold(I) derivatives (values ranging from $10^{1}$ to $10^{3}$ ) [49], but is next to the values found in the anion $\left[\mathrm{Au}(\mathrm{CN})_{2}\right]^{-}[50]$ and in gold(III) complexes $\left(10^{4}-10^{5}\right)[51,52]$, although significantly smaller than the observed in gold nanoparticles (around $10^{8}-10^{10}$ ) $[53,54]$. The experimental value of $\mathrm{K}_{\mathrm{b}}$ of $7.21 \cdot 10^{4} \mathrm{M}^{-1}$ is in accordance with a significant interaction with BSA, which would allow the biodistribution of the drug in plasma. A weak binding gives higher drug concentration in plasma leading to a poor distribution of the

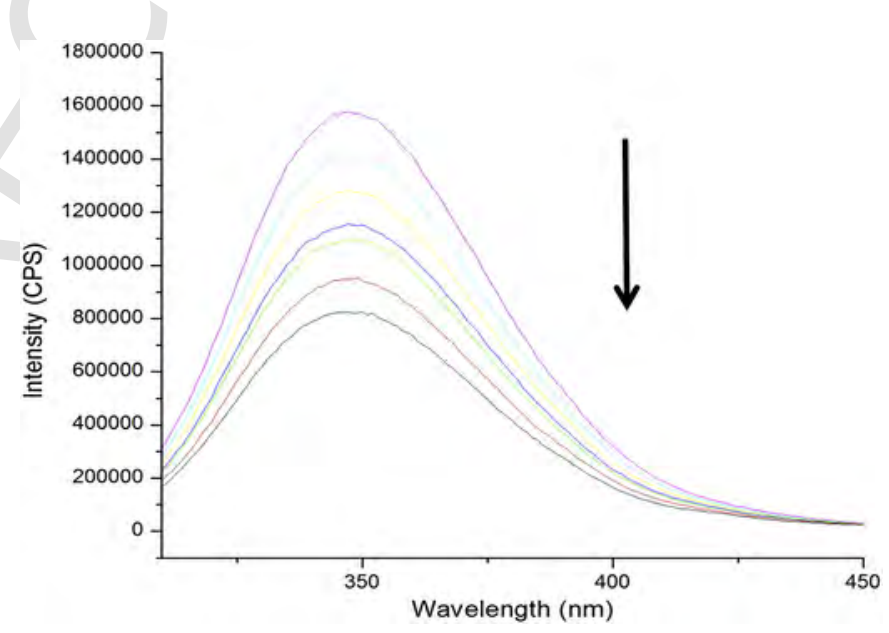

Fig. 1. Fluoresce quenching of BSA in presence of increasing concentration of $[\mathrm{Au}(\mathrm{C}$ $\equiv \mathrm{CPh})(\mathrm{PTA})]$ at $295 \mathrm{~K}$.

Table 1

Values of quenching constant $\left(K_{s v}\right)$, apparent binding constant $\left(K_{b}\right)$, binding sites (n) and thermodynamic parameters for BSA interaction with $[\mathrm{Au}(\mathrm{C} \equiv \mathrm{CPh})(\mathrm{PTA})]$ at different temperatures.

\begin{tabular}{lllllll}
\hline $\mathrm{T}(\mathrm{K})$ & $\mathrm{n}$ & $\begin{array}{l}K_{s v}(\mathrm{~L} \mathrm{~mol} \\
\left(\times 10^{4}\right)\end{array}$ & $K_{b}\left(\mathrm{M}^{-1}\right)$ & $\begin{array}{l}\Delta G^{o} \\
\left(\mathrm{KJ} \mathrm{mol}^{-1}\right)\end{array}$ & $\begin{array}{l}\Delta H^{o} \\
\left(\mathrm{KJ} \mathrm{mol}^{-1}\right)\end{array}$ & $\begin{array}{l}\Delta S^{o} \\
\left(\mathrm{~J} \mathrm{~mol}^{-1} \mathrm{~K}^{-1}\right)\end{array}$ \\
\hline 295 & 1.09 & 2.9 & $7.21 \cdot 10^{4}$ & -27.60 & 161.13 & 639.76 \\
304 & 1.34 & 1.75 & $6.38 \cdot 10^{5}$ & -33.36 & 161.13 & 639.76 \\
310 & 1.44 & 1.61 & $1.66 \cdot 10^{6}$ & -37.20 & 161.13 & 639.76 \\
\hline
\end{tabular}


A

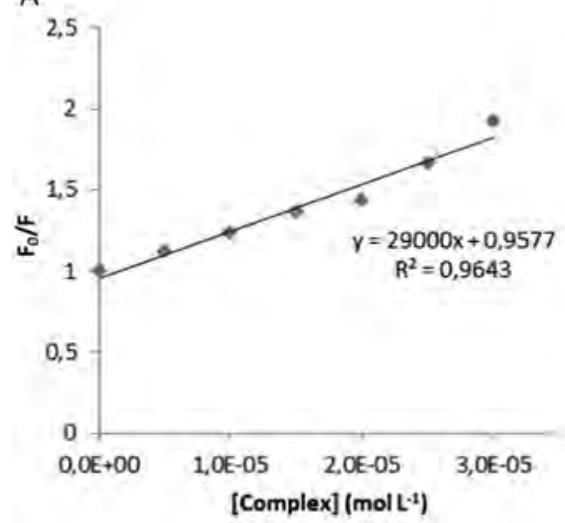

B

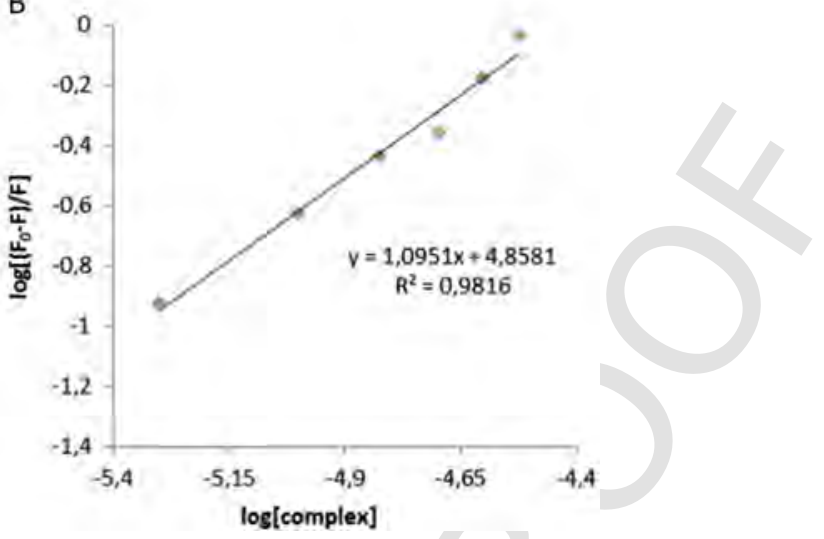

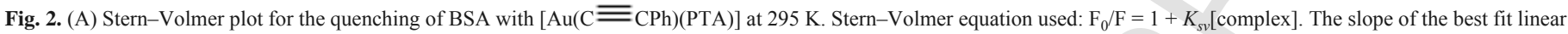

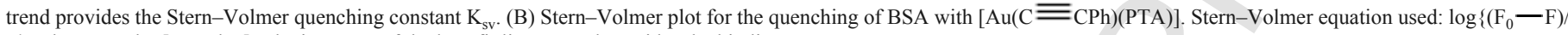
$\mathrm{F}\}=\log K_{b}+n \log \left[\right.$ complex]. The intercept of the best fit linear trend provides the binding constant $\mathrm{K}_{\mathrm{b}}$.

drug, while a strong interaction could improve the distribution and drug pharmacological effect. [55].

A linear Stern-Volmer plot (Fig. 2A) is in accordance with the presence of a single type of quenching mechanism, either static or dynamic [56]. A dynamic quenching is due to collisions between the quenching agent and the fluorophore (BSA in our experiment) and in a static quenching, the quenching agent forms a non-flourescent complex with the fluorophore. Dynamic mechanism depends upon diffusion, which increases with the temperature, consequently the quenching constant $K_{s v}$, is expected to increase with the temperature. Table 1 displays the values of $K_{s v}$ at three temperatures. The results indicate that the Stern-Volmer quenching constant is inversely correlated with temperature, which is agreement with the formation of a complex of the quencher with BSA (static mechanism) [56]. Dynamic or static mechanism can be distinguished by an UV-vis absorption experiment. Collisional quenching only modifies excited states and consequently there should be no changes in the absorption spectra. Conversely, ground-state complex formation (static quenching) frequently results in the presence of modified UV-vis spectrum [57]. The absorption spectra of BSA in the presence and in the absence of $[\mathrm{Au}(\mathrm{C}$ $\equiv \mathrm{CPh}(\mathrm{PTA})]$ at the same concentration at room temperature are recorded in the supplementary material (Fig. S8). A mathematical superposition of the BSA spectrum and the gold derivative spectrum was calculated. The calculated superposition and the corresponding spectrum of BSA in the presence of the gold derivative displays a deviation in the superposition pointing out to a static mechanism as a consequence of a BSA-[Au(C $\equiv \mathrm{CPh})(\mathrm{PTA})]$ complex formation, which is in accordance with the results derived from $\mathrm{K}_{\mathrm{sv}}$ data at different temperatures.

The interaction forces between small molecules and biomolecules include hydrogen bonds, van der Waals forces, electrostatic and hydrophobic attraction [58]. In the study of those interactions, the determination of the sign of the thermodynamic parameters $\Delta G^{\circ}, \Delta H^{\circ}$ and $\Delta S^{\circ}$ is critical. These data were calculated with the van't Hoff equation $K_{b}=-\Delta H^{o} / \mathrm{RT}+\Delta S^{o} / \mathrm{R}$, where $K_{b}$ is the binding constant calculated at different temperatures and $\mathrm{R}$ is the gas constant. The value of enthalpy exchange $\Delta H^{o}$ is calculated from the slope of the plot of $\ln K_{b} v s$. 1/T (Fig. S7, supplementary material) and the free energy change $\Delta G^{o}$ is estimated from the relationship $\Delta G^{o}=\Delta H^{\circ}-\mathrm{T} \Delta S^{\circ}$. In this case, the values of $\Delta H^{\circ}>0$ and $\Delta S^{\circ}>0$ (Table 1) are indicative of the existence of hydrophobic interactions between $[\mathrm{Au}(\mathrm{C} \equiv$ $\mathrm{CPh})(\mathrm{PTA})]$ and BSA and $\Delta G^{\circ}<0$ supports the presence of a spontaneous process. These results correlates with the slight lipophilic nature of $[\mathrm{Au}(\mathrm{C} \equiv \mathrm{CPh})(\mathrm{PTA})]$. Finally, the number of binding sites (n) increases with temperature (Table 1) revealing a dynamic component in the binding between $[\mathrm{Au}(\mathrm{C} \equiv \mathrm{CPh})(\mathrm{PTA})]$ and BSA.

\subsection{Antiproliferative activity}

The cellular effects of $[\mathrm{Au}(\mathrm{C} \equiv \mathrm{CPh})(\mathrm{PTA})]$ have been tested against human colon cancer cell line Caco-2/TC7. This cell line, derived from human colon adenocarcinoma, is considered one of the most regular used for intestinal drug absorption studies. It undergoes spontaneous enterocytic differentiation when cultured over confluence for 21 days to become polarized cells expressing apical and basolateral surfaces with well-established tight junctions. So, we investigated the influence of $[\mathrm{Au}(\mathrm{C} \equiv \mathrm{CPh})(\mathrm{PTA})]$ on the growth and proliferation of Caco-2/TC7.

At first, we investigated the cellular effects of $[\mathrm{Au}(\mathrm{C} \equiv$ $\mathrm{CPh})(\mathrm{PTA})]$ on undifferentiated Caco-2/TC7. Antiproliferative effects -expressed in terms of $\mathrm{IC}_{50}$ values- were observed after exposure to the drug for $72 \mathrm{~h}$, using the well-established MTT assay. The corresponding $\mathrm{IC}_{50}$ value calculated of $2.65 \pm 1.1 \mu \mathrm{M}$ indicates a strong cytotoxic activity of the gold complex.

We compared the effect of $[\mathrm{Au}(\mathrm{C} \equiv \mathrm{CPh})(\mathrm{PTA})]$ on normal enterocytes (Caco-2/TC7 cells under confluence) and also on cancer cells (Caco-2/TC7 cells which not have reached confluence) to predict its behavior on a real colon [59]. We observed a significant reduction in proliferation of $78 \%$ in cancer cells (Fig. 3) while this reduction was absent in normal cells where cell viability was over $91 \%$. MTT as-

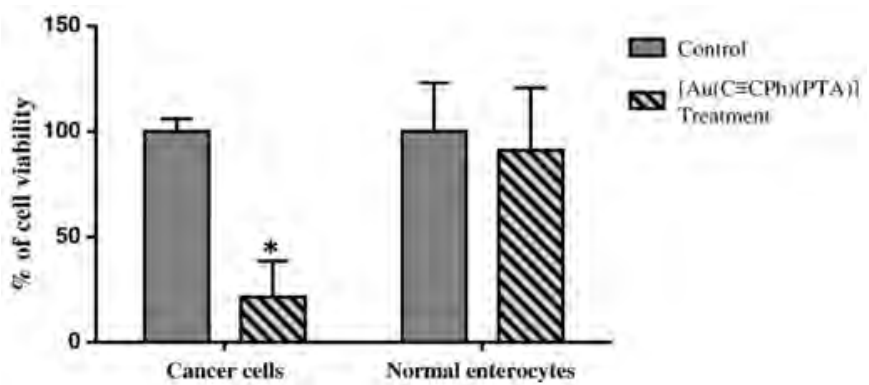

Fig. 3. Cell viability of Caco-2/TC7 cell line upon treatment with $2.65 \mu \mathrm{M}[\mathrm{Au}(\mathrm{C} \equiv$ $\mathrm{CPh})(\mathrm{PTA})]$. Gold complex treatment reduced cancer cells viability in a $78.4 \% \mathrm{com}-$ pared to control cells, whereas it does not affect the viability of differentiated enterocytes. Data are presented as $\%$ of viability compared to control group \pm standard error of 16 independent experiments. ${ }^{*} p<0.01$. (For interpretation of the references to colour in this figure legend, the reader is referred to the web version of this article.) 
says revealed that $[\mathrm{Au}(\mathrm{C} \equiv \mathrm{CPh})(\mathrm{PTA})]$ can stop the uncontrolled proliferation of cancer cells without affecting normal enterocytes; so it appears to selectively target cancer cells.

\section{4. $[A u(C \equiv C P h)(P T A)]$ induces apoptosis in cancer cells}

Since $[\mathrm{Au}(\mathrm{C} \equiv \mathrm{CPh})(\mathrm{PTA})]$ treatment proved to reduce cell viability, we hypothesized that it could induce apoptosis on Caco-2/TC7 cells. To address this hypothesis, we performed flow cytometry analysis of annexin V/propidium iodide-stained Caco-2/TC7 cells. During the early stages of apoptosis, the cell membrane loses asymmetry and the membrane phospholipid phosphatidylserine is translocated from the inner to the outer part of the membrane. Annexin-V (FITC conjugated) specifically binds to phosphatidylserine and can be detected by flow cytometry, thereby allowing the identification of early stage apoptotic cells. Viable cells with intact membranes and cells undergoing early apoptosis but with relatively intact membranes exclude propidium iodide, whereas the membranes of dead and damaged cells are permeable to PI and are also stained with annexin-V.

The cell-state distributions after $24 \mathrm{~h}$ treatment with $[\mathrm{Au}(\mathrm{C} \equiv$ $\mathrm{CPh})(\mathrm{PTA})]$ showed a trong antiproliferative effect in comparison to the control (Fig. 4 and Table 2) on undifferentiated cells. Late apoptotic cell population was higher than positive control (staurosporine) and even higher than early apoptotic events (control-butyrate). Only negligible populations of necrotic cells were detected. (See Table 3.)

We also examined whether $[\mathrm{Au}(\mathrm{C} \equiv \mathrm{CPh})(\mathrm{PTA})]$ could induce apoptosis on normal enterocytes using low cytometry analysis of annexin V/propidium iodide-stained Caco-2/TC7 cells which have reached confluence. Significant number of viable cells were present after $24 \mathrm{~h}$ of incubation with $[\mathrm{Au}(\mathrm{C} \equiv \mathrm{CPh})(\mathrm{PTA})]$, similar to the control (Fig. 4 and Table 2). Again, an increase of necrotic events was not observed.

Chemotherapy-induced apoptosis results very interesting [60] since necrosis can cause various side effects including septic shock and kidney failure that may compromise patient health. In light of this, it is important to notice the absence of necrosis observed. These apoptosis analysis pointed out once again the apparent selectivity of the compound, as it was previously shown in the MTT assay.

\subsection{Role of caspases, pro-apototic and anti-apoptic proteins in $[A u(C \equiv C P h)(P T A)]$-induced apoptosis}

Once apoptosis has been proposed as the cell death mechanism induced by $[\mathrm{Au}(\mathrm{C} \equiv \mathrm{CPh})(\mathrm{PTA})]$, we investigated the role of different caspases, pro-apoptic and anti-apototic proteins in such induced apoptosis. It is already known that anti-apoptotic proteins, such as BCL-2 (B-Cell Lymphoma 2) protect the cell from cytochrome $c$ translocation [61], whereas pro-apoptotic proteins, such as BAX, promotes the permeabilization of the outer membrane of the mitochondrion and hence the efflux of cytochrome $c$ [62]. In the cytoplasm, cytochrome $c$ associates with Apoptosis Protease-Activating Factor-1 (APAF-1) and induces the activation of pro-caspase 9 via proteolytic cleavage [63]. Later, caspase 9 will activate caspase 3, an executioner protein of apoptosis [64].

Firstly, we used flow cytometry to analyze the influence of $[\mathrm{Au}(\mathrm{C}$ $\equiv \mathrm{CPh})(\mathrm{PTA})]$ in the levels of the BAX and BCL-2. Cells treated with $[\mathrm{Au}(\mathrm{C} \equiv \mathrm{CPh})(\mathrm{PTA})]$ for $24 \mathrm{~h}$ showed a 1.6 -fold increase in BAX levels (Fig. 5A and Fig. S9) and a 5.2-fold decrease in BCL-2 levels (Fig. 5B and Fig. S9), demonstrating that $[\mathrm{Au}(\mathrm{C} \equiv \mathrm{CPh})(\mathrm{PTA})]$ can disrupt the balance between pro-apoptotic and anti-apoptotic proteins. In Caco-2/TC7 cells this balance disruption is mainly caused by a reduction of anti-apoptotic proteins rather than an increase of pro-apoptotic signals. Caco-2/TC7 cells, as many colon tumors, harbor mutations in TP53 [65], a protein responsible for the up-regulation of $\mathrm{BAX}$ expression [66]. In consequence, the mutation E204X of TP53 present in Caco-2/TC7 cell line [65] might affect its capacity to bind DNA and induce BAX expression. Nevertheless, it seems that the decrease of BCL-2 levels is sufficient for apoptosis induction in Caco-2/TC7.

The next analyzed step of mitochondrial apoptotic pathway is the alteration of mitochondrial membrane potential (MMP). MMP is generated and maintained by concentration gradients of ions such as sodium, potassium, chloride, and hydrogen. During apoptosis, an uncontrolled production of oxygen radicals, as well as a disruption of the pro-apoptotic $v s$. anti-apoptotic protein balance, stimulates $\mathrm{Ca}^{2+}$ release from mitochondria, and hence $\mathrm{Ca}^{2+}$ cycling. Successively, $\mathrm{Ca}^{2+}$ cycling causes mitochondrial uncoupling, ATP depletion, alteration of mitochondrial potential and massive disturbance of cellular $\mathrm{Ca}^{2+}$ homeostasis, which stimulates $\mathrm{Ca}^{2+}$-dependent endonuclease(s) [67]. Therefore, we analyzed the possible changes in MMP by using the cationic dye DilC1(5) (1,1',3,3,3'-hexamethylindodicarbo-cyanine iodide) and flow cytometry. As it was expected, we found a decrease of MMP in cells treated with $[\mathrm{Au}(\mathrm{C} \equiv \mathrm{CPh})(\mathrm{PTA})]$ compared with control cells (Fig. 6A). These results could indicate that $[\mathrm{Au}(\mathrm{C} \equiv \mathrm{CPh})(\mathrm{PTA})]$ dependent reduction of BCL-2 levels is sufficient to reduce MMP, which is considered as a sign of apoptosis [68]. On the other hand, we observed an increase in the mean fluorescence of $[\mathrm{Au}(\mathrm{C} \equiv \mathrm{CPh})(\mathrm{PTA})]$ treated cells with positive MMP compared to control (Fig. 6B, S9). MMP is generated by a proton gradient across the mitochondrial inner membrane created by the oxidation of substrates. The gold atom contained in $[\mathrm{Au}(\mathrm{C} \equiv \mathrm{CPh})(\mathrm{PTA})]$ could be able to interact with different molecules inside the cell, and also inside the mitochondrion, increasing ROS production and enhancing mitochondrial proton gradient which will result in an increase of MMP. However, when the concentration of ROS reaches a limit, different mitochondrial structures can get damaged such as mitochondrial DNA, lipids and proteins. In particular, ROS target the mitochondrial Permeability Transition Pore (mPTP). mPTP is a multiprotein complex whose core constituted by voltage-dependent anion channel (VDAC), ANT (adenine nucleotide translocator), and cyclophilin D localized in the outer, inner mitochondrial membrane, and mitochondrial matrix respectively. Oxidation of ANT critical thiol group in Cys 160 and Cys257 induces opening of the mPTP. Oxidative modifications of mPTP proteins - induced by ROS or $\mathrm{Ca}^{2+}$ among others modify mitochondrial anion fluxes and $\mathrm{mPTP}$ reaches a high-conductance state, which deregulate the entry of small solutes into the mitochondrial matrix. This phenomenon is called mitochondrial permeability transition (MPT) and results in immediate dissipation of the mitochondrial membrane potential, osmotic swelling of the mitochondrial matrix and collapse of MMP [69]. These evidences suggest that those cells with high MMP could remain in MPT which will be end up in MMP reduction and apoptosis induction.

As we have introduced before, disruption of MMP is tightly related to apoptosis. Decrease in MMP - as we have observed in the study - induces structural changes in mitochondria such as matrix condensation and crests unravelling. These structural changes result in the redistribution of cytochrome $c$ from the inner membrane to the intermembrane space, making it more susceptible to be released [70]. With the aim to discover whether our complex was able to induce mitochondrial permeabilization and cytochrome $c$ release, we used flow cytometry to analyze cytochrome $c$ levels in treated and untreated cells. The results of the experiment showed that $[\mathrm{Au}(\mathrm{C} \equiv$ $\mathrm{CPh})(\mathrm{PTA})]$-treated cells contained a 23\% less of mitochondrial cytochrome $c$ compared to control cells. As the total amount of cy- 
A
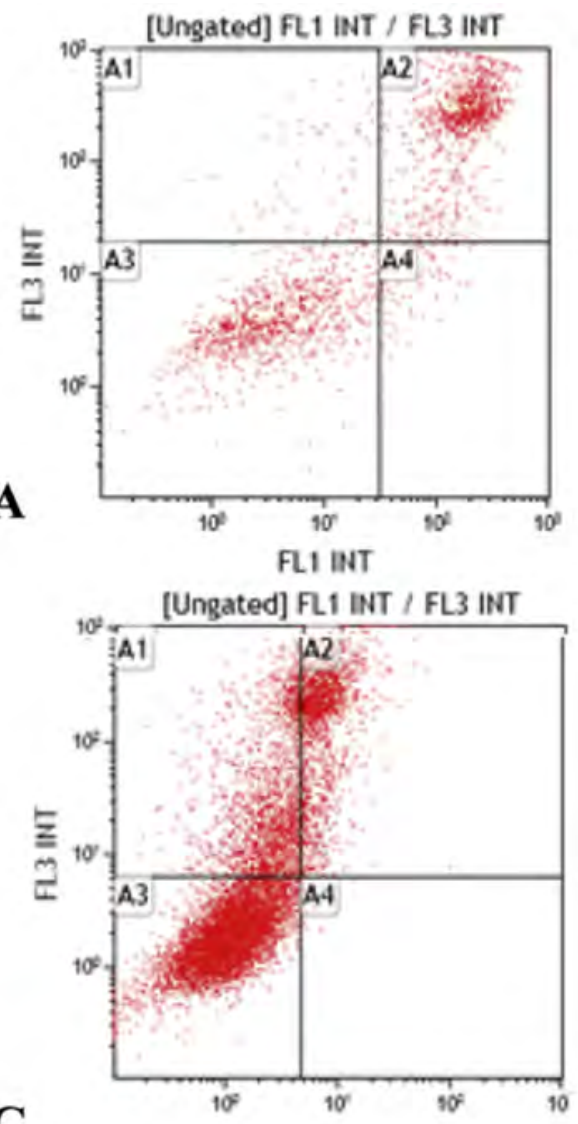

C

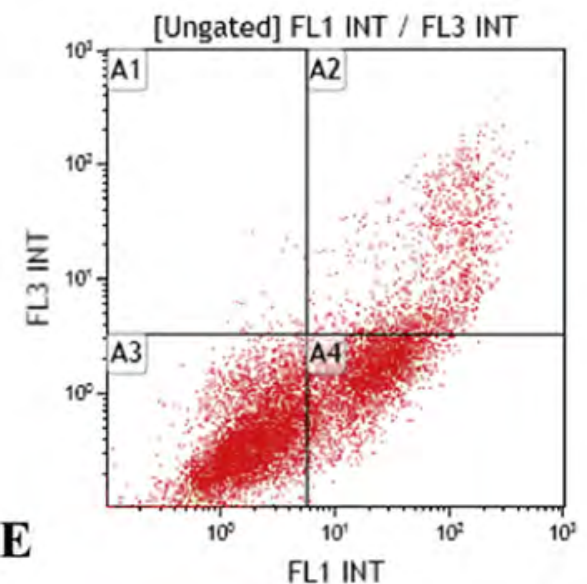

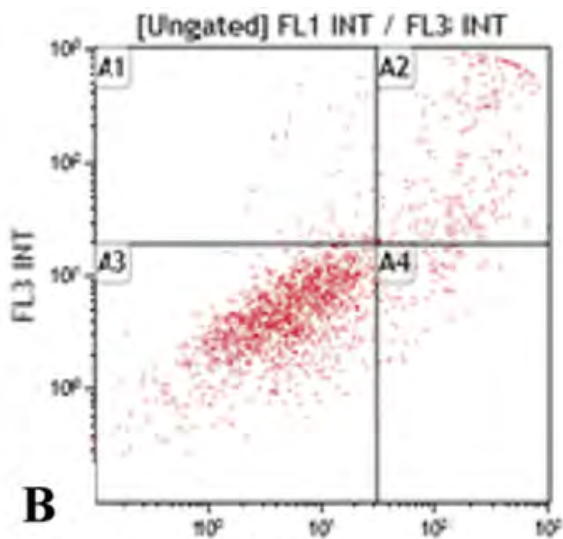

ค.1 INT

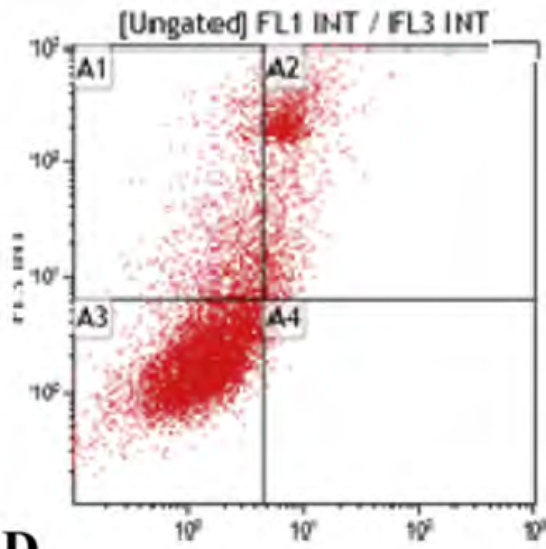

D

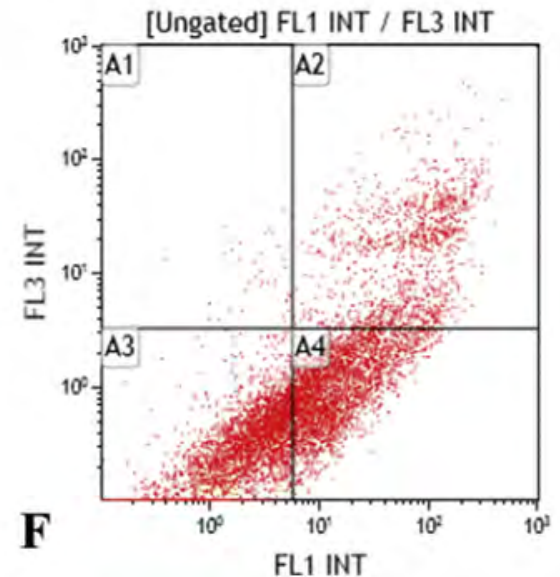

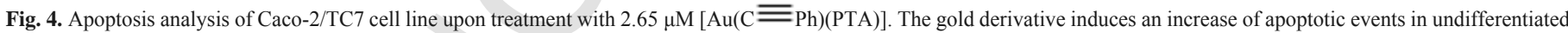

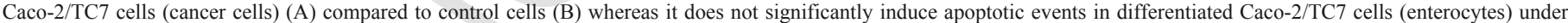

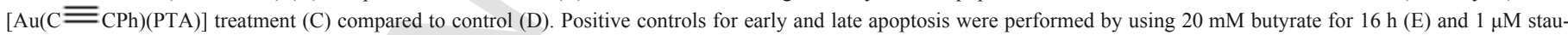
rosporine for $60 \mathrm{~min}(\mathrm{~F})$ treatment respectively. (For interpretation of the references to colour in this figure legend, the reader is referred to the web version of this article.)

tochrome $c$ should be similar in both conditions, a decrease of mitochondrial cytochrome $c$ implies a release of this protein from the mitochondria to the cytoplasm (Fig. 7 and Fig. S9).

Once cytochrome $c$ is released to the cytoplasm, it could bind to and activate the Apoptosis Protease-Activating Factor-1 (APAF-1). Afterwards, the gold complex will bind to ATP/dATP, constituting the apoptosome, which will mediate the activation of caspase- 9 by proteolytic cleavage of pro-caspase 9 [71]. Levels of active caspase- 9 were determined by flow cytometry in complex-treated cells and compared with those in control cells. Our results showed a slight increase of 1.13-fold of active caspase-9 levels in treated cells compared to control cells (Fig. 8A). Although this results suggest that $[\mathrm{Au}(\mathrm{C} \equiv$ $\mathrm{CPh})(\mathrm{PTA})]$ do not induce a high activation of caspase-9 in the first $24 \mathrm{~h}$ after treatment, we investigate whether this increase in the levels of active caspase- 9 could be sufficient for the execution of apoptosis.

The last step in the intrinsic apoptosis pathway is the activation of the effector caspases such as caspase-3. Caspase- 3 is activated by a proteolytic cleavage induced by initiator caspases. In this process we 
Table 2

Apoptotic percentages of Caco-2/TC7 cell line upon treatment with $2.65 \mu \mathrm{M}$ $[\mathrm{Au}(\mathrm{C}=\mathrm{CPh})(\mathrm{PTA})]$. Summary of differentiated (enterocytes) and undifferentiated Caco-2/TC7 cells (cancer cells) treated with $[\mathrm{Au}(\mathrm{C}=\mathrm{CPh})(\mathrm{PTA})]$ and compared with negative control (untreated cells), and positive controls for early apoptosis ( $20 \mathrm{mM}$ butyrate for $16 \mathrm{~h}$ ) and late apoptosis $(1 \mu \mathrm{M}$ staurosporine for $60 \mathrm{~min})$.

\begin{tabular}{|c|c|c|c|c|c|}
\hline Cells & Treatment & $\begin{array}{l}\text { Live } \\
(\%)\end{array}$ & $\begin{array}{l}\text { Early } \\
\text { apoptosis } \\
(\%)\end{array}$ & $\begin{array}{l}\text { Late } \\
\text { apoptosis } \\
(\%)\end{array}$ & $\begin{array}{l}\text { Necrosis } \\
(\%)\end{array}$ \\
\hline Undifferentiated & $\begin{array}{l}\text { Negative } \\
\text { control }\end{array}$ & 78.89 & 5.84 & 11.78 & 2.5 \\
\hline Undifferentiated & Butyrate & 55.85 & 32.11 & 11.75 & 0.29 \\
\hline Undifferentiated & Staurosporine & 43.34 & 15.49 & 40.7 & 0.47 \\
\hline Undifferentiated & $\begin{array}{l}{[A u(C \overline{\bar{\equiv}}} \\
C P h)(P T A)]\end{array}$ & 43.62 & 4.65 & 48.66 & 3.07 \\
\hline Differentiated & $\begin{array}{l}\text { Negative } \\
\text { control }\end{array}$ & 66.0 & 16.3 & 15.9 & 1.7 \\
\hline Differentiated & $\begin{array}{l}{[A u(C \bar{\equiv}} \\
C P h)(P T A)]\end{array}$ & 72.86 & 2.78 & 15.53 & 8.83 \\
\hline
\end{tabular}

Table 3

Thiol-reductase activity in Caco-2 cell lysates. The thiol-reductase activity was measured as the increase of absorbance at $412 \mathrm{~nm}$ per minute in the regular DTNB assay and corrected by the total amount of protein present in the cell lysate. Values in parenthesis represent the percentage of activity related to control $(* P<0.05)$.

\begin{tabular}{ll}
\hline Condition & Thiol-reductase activity $\left(\mu \mathrm{mol} \mathrm{mg}^{-1} \mathrm{~min}^{-1}\right)$ \\
\hline Control & $0.150 \pm 0.029(100 \%)$ \\
{$[\mathrm{Au}(\mathrm{C} \equiv \mathrm{CPh})(\mathrm{PTA})]$} & $0.130 \pm 0.014(85.84 \%)^{*}$ \\
\hline
\end{tabular}

would like to highlight the role of caspase- 8 and -9 which connect with the extrinsic and intrinsic apoptotic pathways respectively [71]. Once capase- 3 has been activated, it induces the proteolytic cleavage
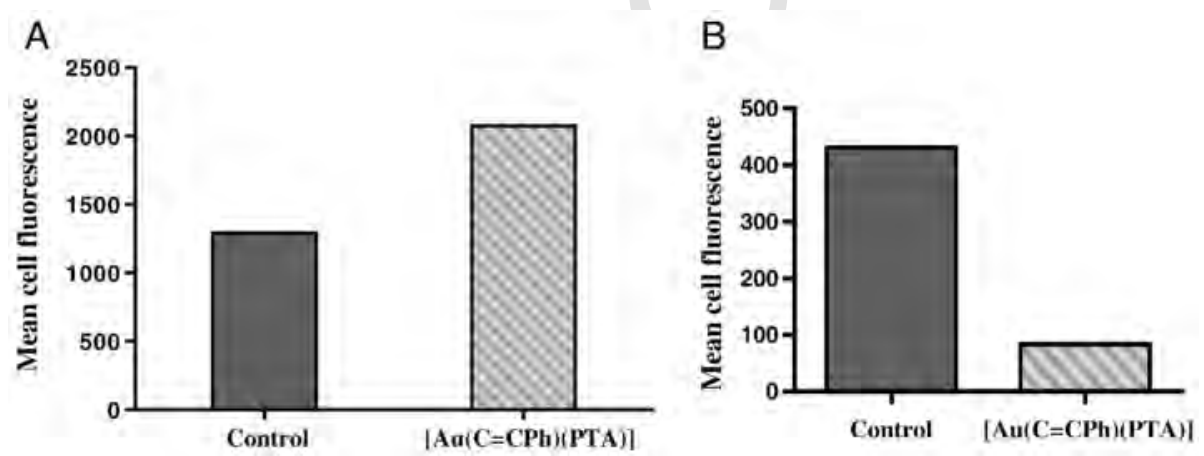

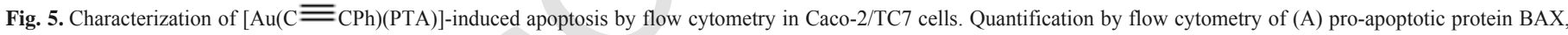
(B) anti-apoptotic protein BCL-2. Results are expressed in mean arbitrary units.

A

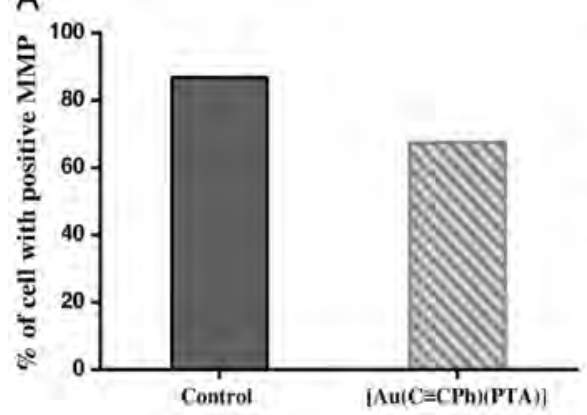

of a large number of essential proteins for apoptosis [72]. Due to the key role of caspase-3 in both extrinsic and intrinsic apoptotic pathways, we analyzed the levels of capase- 3 in $[\mathrm{Au}(\mathrm{C} \equiv \mathrm{CPh})(\mathrm{PTA})]$ treated cells by flow cytometry. We found a 1.5 -fold increase of capsase- 3 levels in treated cells compared to control (Fig. 8B and Fig. S9). This increase in active capase-3 seems to be sufficient for apoptosis induction in Caco-2/TC7 cells. Moreover, this results suggest that the slight increase of active caspase-9 levels found in $\mathrm{Au}(\mathrm{C} \equiv$ $\mathrm{CPh})(\mathrm{PTA})]$ treated cells could be sufficient for initiating the apoptotic process, although the participation of other apoptotic pathways cannot be discarded.

Consequently, our results suggest that $[\mathrm{Au}(\mathrm{C} \equiv \mathrm{CPh})(\mathrm{PTA})]$ disrupts the balance of anti-apoptotic versus pro-apoptotic proteins by decreasing anti-apoptotic proteins levels and inducing mitochondrial permeability transition (MPT) which alters mitochondrion permeability and triggers MMP reduction as well as cytochrome $c$ release. These alterations promote the activation of the caspase cascade that culminates in the execution of apoptosis.

\subsection{Cell cycle modification}

Since cell proliferation was inhibited by $[\mathrm{Au}(\mathrm{C} \equiv \mathrm{CPh})(\mathrm{PTA})]$, we investigated whether this compound could induce a sort of alteration of cycling-dependent kinases. Previous studies from Li et al. [73] showed that some chemotherapeutics could reduce cyclin $B 1$ and Cdc1 expression and increase p53, p21waf1/cip1, p27kip1 and Gad$\mathrm{d} 45$ transcription, which produce an arrest in phase $\mathrm{G}_{2}-\mathrm{M}$. Those modifications in protein expression could be promoted by an increase in ROS levels [74].

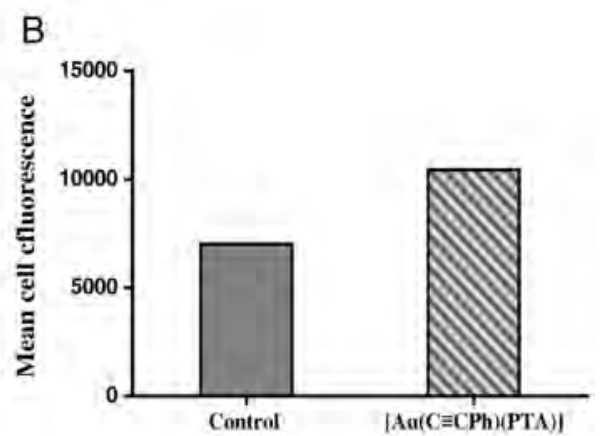

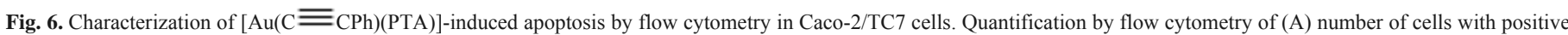
MMP, (B) mean MMP per cell. Results are expressed in arbitrary units. 


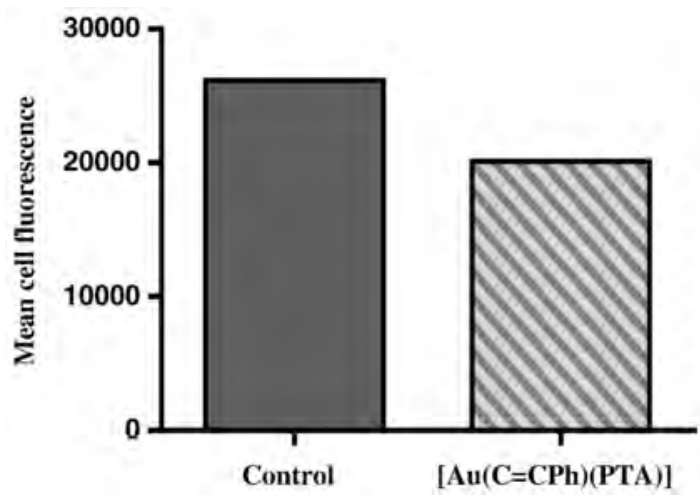

Fig. 7. Quantification of mitochondrial cytochrome $c$ by flow cytometry in $[\mathrm{Au}(\mathrm{C} \equiv$ $\mathrm{CPh})(\mathrm{PTA})]$-treated Caco-2/TC7 cells. Results are expressed as arbitrary fluorescence units.

Cell cycle analysis of cancer cells treated with $[\mathrm{Au}(\mathrm{C} \equiv$ $\mathrm{CPh})(\mathrm{PTA})]$ showed a reduction of the events on $\mathrm{G}_{2}$ (Fig. 9B), which is consistent with the reduction of cell proliferation triggered by this compound. Nevertheless, results in differentiated Caco-2/TC7 cells showed that $[\mathrm{Au}(\mathrm{C} \equiv \mathrm{CPh})(\mathrm{PTA})]$ does not affect to cell cycle of normal enterocytes (Fig. 9D), another proof of the apparent selectivity of $[\mathrm{Au}(\mathrm{C} \equiv \mathrm{CPh})(\mathrm{PTA})]$ in cancerous cells.

\subsection{Interaction with nucleic acids}

DNA has been identified as one of the main targets for most of the current drugs employed in advanced clinical trials. Some metal based anticancer drugs interact with nucleic acids by covalent binding and/or intercalation, being the platinum like metallodrugs the most known examples $[75,76]$. However the occurrence of several disadvantages, that includes important side effects and intrinsic or acquired resistance, from the use of cisplatin and its analogs, has favored the development of new cytotoxic metallodrugs with DNA independent mechanism of action [77,78].

To analyze DNA integrity and to detect a possible interaction between $[\mathrm{Au}(\mathrm{C} \equiv \mathrm{CPh})(\mathrm{PTA})]$ and nucleoids, we firstly analyzed the reactivity of $[\mathrm{Au}(\mathrm{C} \equiv \mathrm{CPh})(\mathrm{PTA})]$ complex and the plasmid pIRES2-EGFP (5308 pb) in vitro. The SDS-PAGE showed that treatment with increasing amounts of the gold complex does not affect the mobility of the plasmid, conversely with the observed in cisplatin that is in accordance with the lack of interaction with the plasmid pIRES2-EGFP (DNA) (Fig. S10).
Then, the reactivity of $[\mathrm{Au}(\mathrm{C} \equiv \mathrm{CPh})(\mathrm{PTA})]$ with DNA was evaluated in cells. We isolated DNA from Caco-2/TC7 cells treated with the gold complex for $24 \mathrm{~h}$ and then agarose gel electrophoresis study was performed (Fig. 10A). DNA electrophoresis revealed a single band in each condition with a similar molecular weight to negative control, suggesting that $[\mathrm{Au}(\mathrm{C} \equiv \mathrm{CPh})(\mathrm{PTA})]$ did not form mono adducts with DNA as cisplatin does [79].

Likewise, DNA electrophoresis showed an absence of the internucleosomal fragmentation and a DNA ladder pattern -one of the main biochemical hallmarks of apoptosis [80]- in $[\mathrm{Au}(\mathrm{C} \equiv$ $\mathrm{CPh})(\mathrm{PTA})]$-treated cells (Fig. 10A), neither it could be detected in our positive controls for apoptosis, butyrate and staurosporine (Fig. 10B). These results correlate with the absence of DNA fragmentation in some cell lines as Caco-2/TC7, where this ladder pattern cannot be seen [81]. When a cell dies through apoptosis, its chromatin is condensed and then broken into internucleosomal fragments by endonucleases like DF40, which is activated by caspase-3. This fragmentation takes place in a later steps of apoptosis, so is absent, joined to the results of caspases activation obtained by flow cytometery, might indicate that analyzed Caco-2/TC7 remained in the early stage of the process [82]. Deficiencies in DF40 could also explain the absence of the ladder pattern obtained in our SDS-PAGE.

Cisplatin is also capable of binding RNA and preventing its translation to proteins [83]. Nevertheless $[\mathrm{Au}(\mathrm{C} \equiv \mathrm{CPh})(\mathrm{PTA})]$ did not display any interaction as can be deduced from SDS-PAGE electrophoresis studies of the total RNA isolated from Caco-2/TC7 cells treated with the gold derivative, confirming the initial hypothesis of a different mechanism of action. We observed three different bands corresponding to $28 \mathrm{~S}$ rRNA, $18 \mathrm{~S}$ rRNA and tRNA without degradation or retardation in their migration (Fig. 11). Again, dissimilarities at atomic level between gold and platinum may explain the inability of $[\mathrm{Au}(\mathrm{C} \equiv \mathrm{CPh})(\mathrm{PTA})]$ to interact with RNA as cisplatin does.

\subsection{Effects on ROS formation}

As our previous results in flow cytometry report, mitochondria seems to be altered by the treatment with $[\mathrm{Au}(\mathrm{C} \equiv \mathrm{CPh})(\mathrm{PTA})]$. Considering that this organelle is a natural source of ROS, and having into account that ROS generation may be a cause or even a consequence of the mitochondrial permeability transition pore opening and mitochondrial alterations in apoptosis [84], we consequently studied ROS formation in Caco-2/TC7 cells in response to gold treatment after $24 \mathrm{~h}$ using the fluorogenic freely permeable tracer DCFH-DA. Our results showed that $[\mathrm{Au}(\mathrm{C} \equiv \mathrm{CPh})(\mathrm{PTA})]$ induced a notable increase in ROS production of 1.22-fold compared to mock-treated cells (Fig. 12); increase which was even higher than the obtained with
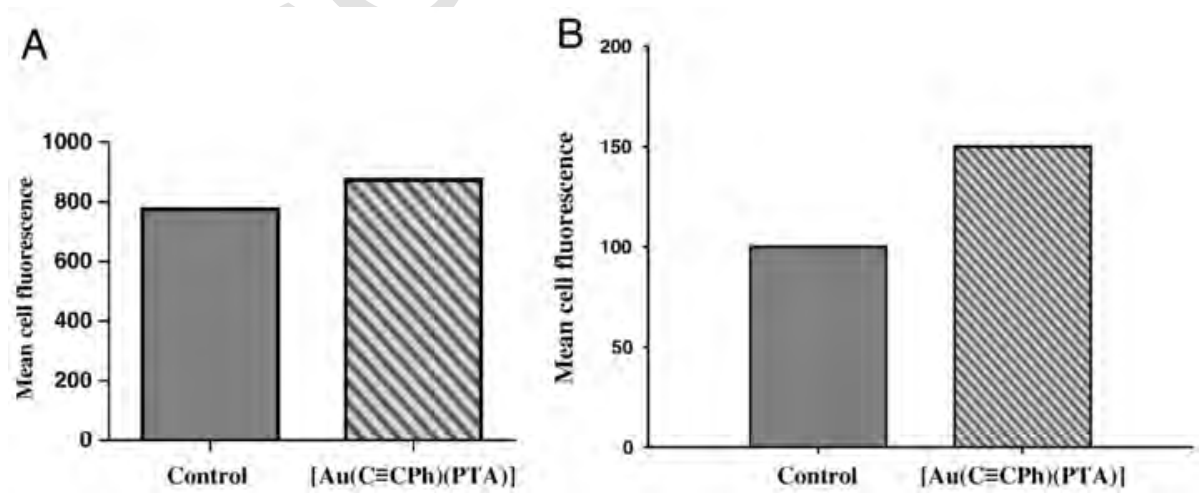

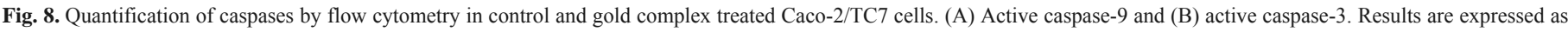
arbitrary fluorescence units. (For interpretation of the references to colour in this figure legend, the reader is referred to the web version of this article.) 

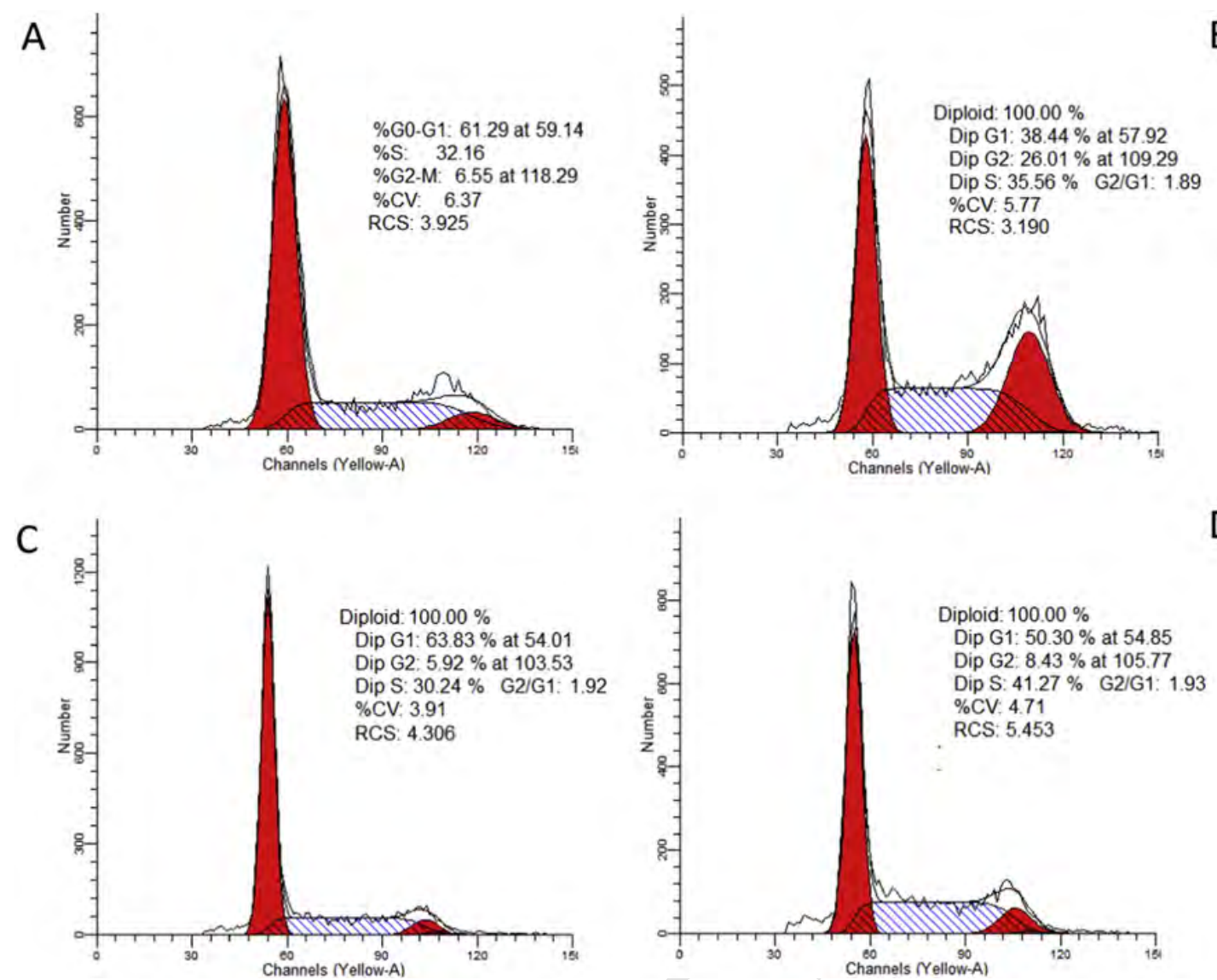

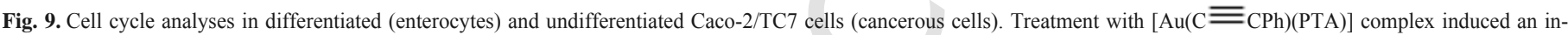

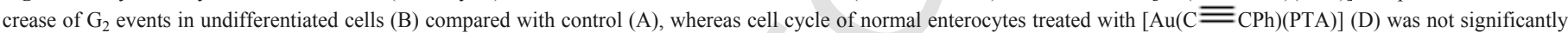
affected compared to cell cycle of untreated differentiated caco-2/TC7 cells (C).

A

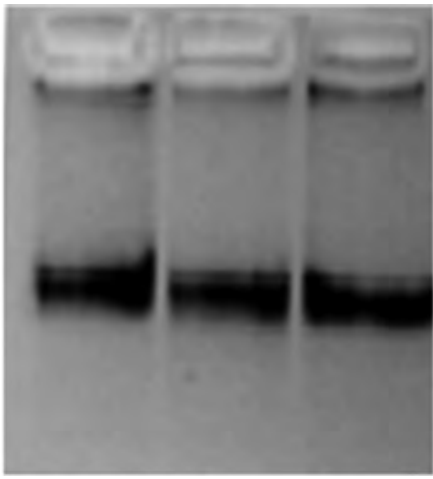

$\mathrm{B}$

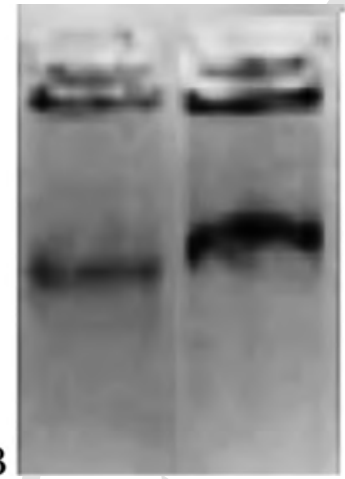

Fig. 10. Interaction between nuclear DNA of $\mathrm{Caco}-2 / \mathrm{TC} 7$ cells and $[\mathrm{Au}(\mathrm{C} \equiv$ $\mathrm{CPh}$ (PTA)]. Electrophoresis of Caco-2/TC7 nuclear DNA. (A) Line 1 untreated cells; lines 2-3 2.65 $\mu \mathrm{M}[\mathrm{Au}(\mathrm{C} \equiv \mathrm{CPh})(\mathrm{PTA})]$-treated cells. (B) Positive controls for apoptosis: line 4 cell treated with staurosporine; line 5 cells treated with butyrate.

cells treated with the well-known gold based antirheumatic drug auranofin. This increase in ROS levels triggered by gold (I) atoms correlates with the finding published previously in the literature [85-87].

\subsection{Thiol-reductase activity in cell lysates}

The results obtained in ROS determination lead us to postulate a modification of redox-defences as an hypothetical action mechanism
B

D 


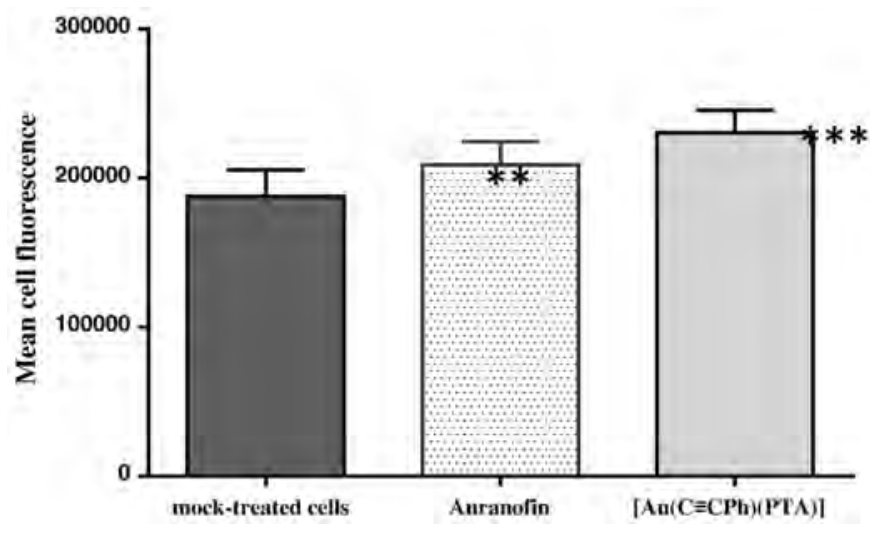

Fig. 12. Quantification of ROS by DCFH-DA method $80 \mathrm{~min}$. DCFH-DA fluoresce at $80 \mathrm{~min}$ showed higher levels of total intracellular ROS in cells under $[\mathrm{Au}(\mathrm{C} \equiv$ $\mathrm{CPh})(\mathrm{PTA})]$ treatment than those for negative - mock treated cells - and positive - auranofin treated cells - controls. Results are expressed in arbitrary units. $(* * P<0.005$; $* * * P<0.001)$

for $[\mathrm{Au}(\mathrm{C} \equiv \mathrm{CPh})(\mathrm{PTA})]$ complex. Reactive oxygen species production in cells is inevitable, however an excessive ROS production is considered harmful to cells. There are some enzymatic and non enzymatic antioxidant systems able to neutralize ROS, such as the glutathione (GSH) and thioredoxin (Trx) systems. In this context, Thioredoxin reductase (TrxR) together with Glutathion reductase (GSR), with selenocysteine and cysteine active sites, respectively, provide reducing equivalents needed in many cellular processes. As stated above, gold(I) which is defined as a 'soft' acid, has strong affinity for 'soft' bases such as selenium and sulphur containing molecules. Consequently gold(I) derivatives can be considered as potential enzyme inhibitors [32]. Since most of the antioxidant defences are based on the presence of sulfhidryl groups, we firstly investigate the capacity of $[\mathrm{Au}(\mathrm{C} \equiv \mathrm{CPh})(\mathrm{PTA})]$ complex to modify the levels of total reduced thiol groups and hence to inhibit the thiol reductase activity in cell lysates using a colorimetric assay. Our results showed a decrease of the thiol-reductase activity in treated cells lysate compared to mock-treated control.

\subsection{Glutathione reductase and thioredoxin reductase activity}

As we have previously mentioned, Thioredoxin reductase and Glutathione reductase are two of the most important cell systems responsible for the maintenance of ROS balance and its activity depend on the presence of a reduced sulphydryl group. In consequence, we determined whether this reduction of thiol reductase activity in cell lysates triggered by $[\mathrm{Au}(\mathrm{C} \equiv \mathrm{CPh})(\mathrm{PTA})]$ could affect to the activity of Thioredoxine reductase and Glutation reductase.

Our results showed that $[\mathrm{Au}(\mathrm{C} \equiv \mathrm{CPh})(\mathrm{PTA})]$ was able to inhibit TrxR1 activity in vitro in a dose-dependent manner (Table 4) whereas Glutation reductase activity did not result reduced, on contrary a slightly increase in its activity was detected, probably induced by the increase in ROS species triggered by $[\mathrm{Au}(\mathrm{C} \equiv \mathrm{CPh})(\mathrm{PTA})]$ (Table 5). The capability of $[\mathrm{Au}(\mathrm{C} \equiv \mathrm{CPh})(\mathrm{PTA})]$ to reduce TrxR but not GSR activity in cells can be explained by the differences found in the active sites of both enzymes. The redox active site of TrxR consist on a selenylsulfide/selenothiol motif localized in the $\mathrm{C}$-terminal tetrapeptide -Gly-Cys-Sec-Gly-COOH which receives the electrons from another redox-active site -Cys-Val-Asn-Val-Gly-Cys- present in the N-terminal domain of the paired subunit of the active dimer. This selenylsulfide/selenothiol motif localized in the $\mathrm{C}$-terminal results easily accessible for drugs, allowing $[\mathrm{Au}(\mathrm{C} \equiv \mathrm{CPh})(\mathrm{PTA})]$ to target the selenocystein present in this group, inhibiting its enzymatic activ-
Table 4

Inhibitory effects of $[\mathrm{Au}(\mathrm{C} \equiv \mathrm{CPh})(\mathrm{PTA})]$ on Thioredoxin reductase 1 (TrxR1) at $\mathrm{IC}_{50}$ and $2 \mathrm{xIC}_{50}$ concentrations. TrxR activity was measured as the increase of absorbance at $412 \mathrm{~nm}$ per minute. Values are given as mean \pm SD of nine independent experiments. Values in parenthesis represent the percentage of activity related to control.

\begin{tabular}{ll}
\hline Conditions & Specific TrxR1 activity $\left(\mu \mathrm{mol} \mathrm{mg}^{-1} \mathrm{~min}^{-1}\right)$ \\
\hline Control & $0.296 \pm 0.032(100 \%)$ \\
{$[\mathrm{Au}(\mathrm{C} \equiv \mathrm{\equiv Ph})(\mathrm{PTA})]$} & $0.215 \pm 0.028(72.63 \%)^{*}$ \\
{$[\mathrm{Au}(\mathrm{C} \equiv \mathrm{CPh}(\mathrm{PTA})](2 \times)$} & $0.192 \pm 0.024(64.86 \%)^{* * * *}$ \\
\hline
\end{tabular}

$* P<0.05$

**** $P<0.005$.

Table 5

Glutathione reductase activity of Caco-2 cell lysates. Glutathione reductase activity was measured as the NADPH consumption, which was determined by the reduction of absorbance at $340 \mathrm{~nm}$ per minute. Values are given as mean $\pm \mathrm{SD}$ of nine independent experiments. Values in parenthesis represent the percentage of activity related to control $(* P<0.05)$.

\begin{tabular}{ll}
\hline Condition & Glutathione Reductase Activity $\left(\right.$ nmol $\left.\cdot \mathrm{min}^{-1}\right)$ \\
\hline $\mathrm{d}$ & $1.552 \pm 0.332$ \\
{$[\mathrm{Au}(\mathrm{C} \equiv \mathrm{CPh})(\mathrm{PTA})]$} & $1.748 \pm 0.529(112.67 \%)$ \\
\hline
\end{tabular}

ity [88]. On the other hand, GSR lack of this a selenylsulfide/selenothiol motif and in consequence the access of drugs in general, and $[\mathrm{Au}(\mathrm{C} \equiv \mathrm{CPh})(\mathrm{PTA})]$ in particular, to the active centre might be hamper, impeding drug inhibition. The inhibition of TrxR activity has been also found in different alkynyl gold(I) derivatives reported previously [89-93]. These results suggest a selectivity of gold alkynyl compounds towards TrxR over other related enzymes such as GSR, as it was previously described in the literature by Meyer et al. [93].

\subsection{Thioredoxin reductase expression}

Finally, we investigated if $[\mathrm{Au}(\mathrm{C} \equiv \mathrm{CPh})(\mathrm{PTA})]$ treatment could affect not only TrxR activity but also its expression. We firstly analyzed by qRT-PCR the effects of $[\mathrm{Au}(\mathrm{C} \equiv \mathrm{CPh})(\mathrm{PTA})]$ in Thioredoxin reductase 1 (TXNRD1) and Thioredoxin (TXN) mRNA expression. We found that the inhibition of TXNRD1 triggered by $[\mathrm{Au}(\mathrm{C} \equiv$ $\mathrm{CPh})(\mathrm{PTA})]$ induces an increase of both $T X N D R 1$ and $T X N$ expression in tumour cells, being the more exacerbate the first one (Fig. 13).

Then, we wanted to corroborate whether those changes in TXN$R D 1$ mRNA were translated at protein levels. To achieve this aim, we analyzed the levels of TXNRD1 in mocked and $[\mathrm{Au}(\mathrm{C} \equiv \mathrm{CPh})(\mathrm{PTA})]$ treated cells by flow cytometry, finding a 1.35-fold increase of TXNDR1 protein quantity in treated cells compared to control cells (Fig. 14).

The regulation of TrxR1 activity in cells involves a complex interaction of many different factors which act at different genetic levels. $T X N R D 1$ transcription is controlled by a strong promoter that ensures high constitutive levels of TXNRDImRNA. This mRNA harbours a 3' untraslated Adenylate-Uridylate-rich elements (AREs) which regulates its stability. Under normal conditions, TXNRDImRNA lifetime is very short, but, upon different stimuli - such as an increase in ROS triggered by TrxR1 inhibition itself - ARE motif stabilizes TXNRD1 mRNA, enabling a quick increase in TrxR1 protein levels [94,95]. Nevertheless, this newly synthetized TrxR 1 is rapidly inactivated by $[\mathrm{Au}(\mathrm{C} \equiv \mathrm{CPh})(\mathrm{PTA})]$ and the exacerbated ROS levels present inside the cell. In consequence, although cells are able to unregulated their ROS defences to fight against $[\mathrm{Au}(\mathrm{C} \equiv \mathrm{CPh})(\mathrm{PTA})]$ they cannot manage their internal ROS levels, and hence mitochondrial apoptotic 

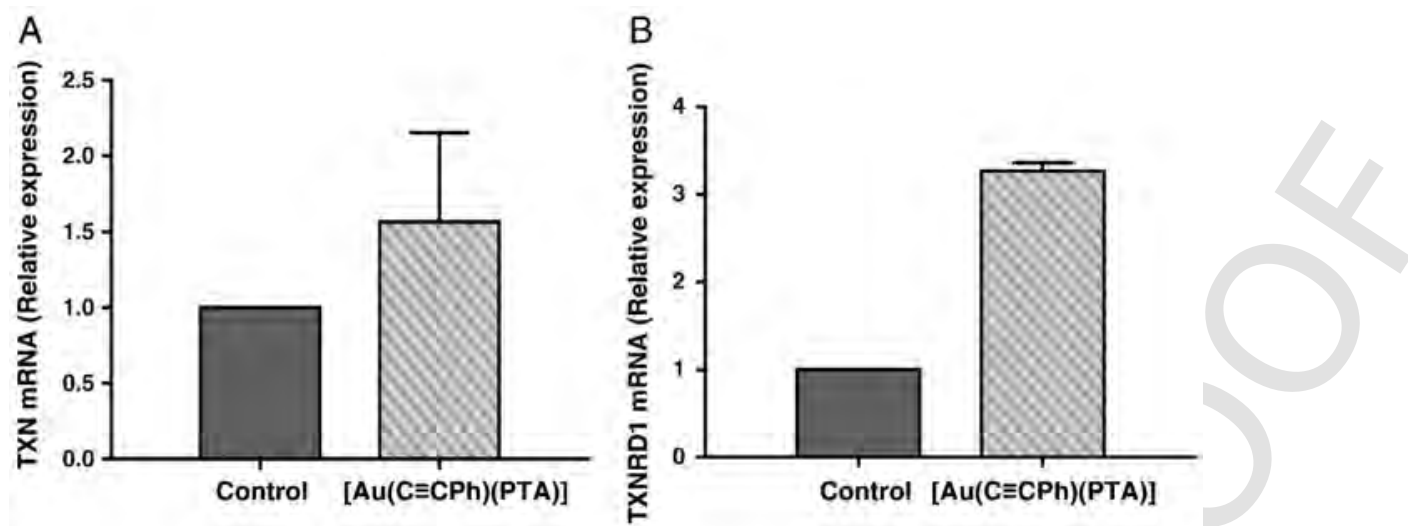

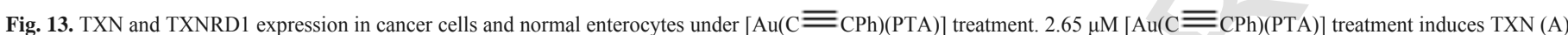
and TXNRD1 (B) transcription demonstrated by qRT-PCR. Graphs show a representative experiment of two with the mean value ( \pm standard deviation) o triplicate amplification.

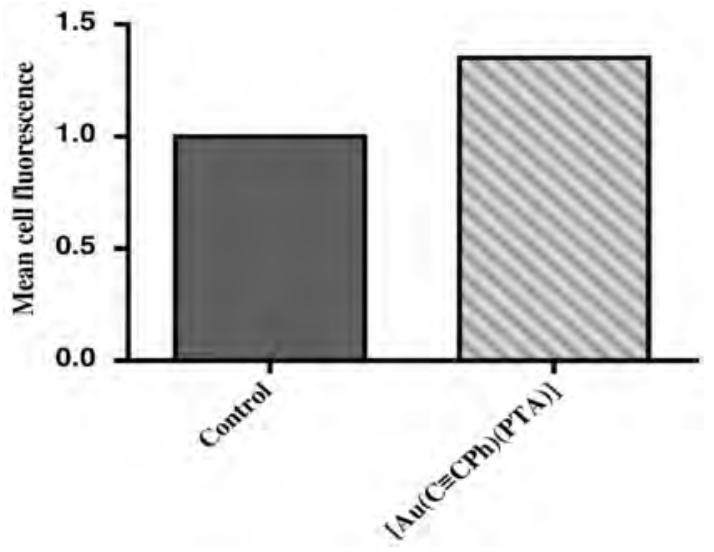

Fig. 14. TrxR 1 protein expression in undiferenciated Caco-2/TC7 cells under $2.65 \mu \mathrm{M}$ $[\mathrm{Au}(\mathrm{C} \equiv \mathrm{CPh})(\mathrm{PTA})]$ treatment. $[\mathrm{Au}(\mathrm{C} \equiv \mathrm{CPh})(\mathrm{PTA})]$ treatment induces TrxR1 overexpression. TrxR1 protein was quantified by flow cytometry. Results are expressed as arbitrary fluoresce units.

mechanism are activated, ending this process with the death of the tumour cell.

\section{Conclusions}

In conclusion we have demonstrated a slight lipophilic character, chemical stability in buffered solution and good anticancer activity in the previously reported gold(I) alkynyl $[\mathrm{Au}(\mathrm{C} \equiv \mathrm{CPh})(\mathrm{PTA})]$. The main disadvantage of lipophilic drugs resides in the complications for their administration and blood transport. However in our case this difficulties lack of importance to some extent, since $[\mathrm{Au}(\mathrm{C} \equiv$ $\mathrm{CPh})(\mathrm{PTA})]$ can bind to BSA through hydrophobic interaction, enabling its transport in the blood.

On the other hand, in vitro assays demonstrated a high antiproliferative activity of $[\mathrm{Au}(\mathrm{C} \equiv \mathrm{CPh})(\mathrm{PTA})]$, which seems to be selective for cancer cells. This cytotoxicity is caused by the inhibition of selenoproteins such as Thioredoxin Reductase 1. The inhibition of this enzyme produces an increase in ROS levels which induce apoptosis directly - by targeting $\mathrm{MPTP}$ and inducing MPT that results in a dissipation of MMP and release of cytochrome $c$ - and indirectly by altering the balance between pro-apoptotic and anti-apoptotic proteins. Both pathways end in the activation of caspase 9, caspase 3 and execution of apoptosis. Another consequence is a reduction in cell proliferation which also promotes changes in the cell cycle such as a de- crease of events in $\mathrm{G}_{2}$. However, unlike cisplatin, $[\mathrm{Au}(\mathrm{C} \equiv$ $\mathrm{CPh})(\mathrm{PTA})]$ does not interact with nucleic acids -DNA or RNA-, reducing the risk of producing genomic mutations and hence decreasing the side effects of anti-tumoral therapy.

All the obtained results predict a promising future for $[\mathrm{Au}(\mathrm{C} \equiv$ $\mathrm{CPh})(\mathrm{PTA})]$ as a chemotherapeutic agent for $\mathrm{CRC}$, nevertheless, further studies should be done in this field. For instance, $[\mathrm{Au}(\mathrm{C} \equiv$ $\mathrm{CPh})(\mathrm{PTA})]$ pharmacodynamics needs to be deeply addressed, as well as the $[\mathrm{Au}(\mathrm{C} \equiv \mathrm{CPh})(\mathrm{PTA})]$ anti-proliferative activity in $3 \mathrm{D}$ cultures and in vivo models. Finally, the capacity of $[\mathrm{Au}(\mathrm{C} \equiv \mathrm{CPh})(\mathrm{PTA})]$ to target other selenoproteins should be studied. Nevertheless, this study provides the first evidences to demonstrate that $[\mathrm{Au}(\mathrm{C} \equiv \mathrm{CPh})(\mathrm{PTA})]$ induce apoptosis, nor necrosis, in CRC cells by altering redox balance.

\begin{tabular}{ll} 
Abbreviations & \\
ANT & Adenine nucleotide translocator \\
APAF & Apoptotic Peptidase Activating Factor \\
ATP & Adenosine Triphosphate \\
BCL-2 & B-Cell Lymphoma 2) \\
BSA & Bovin Serum Albumin \\
CDCl & Deuterochloroform \\
CRC & Colorectal Cancer \\
DMSO & Dimethyl sulfoxide \\
DILC-1(5) & 1,1',3,3,3'-hexamethylindodicarbo-cyanine iodide \\
DCFH-DA & dichloro-dihydro-fluorescein diacetate \\
DTNB & 5,5-dithio-bis-(2-nitrobenzoic acid) \\
EDTA & Ethylenediaminetetraacetic acid \\
FAD & Flavin Adenine Dinucleotide \\
FBS & Fetal Bovine Serum \\
GSH & Glutathione \\
GSR & Glutathione Reductase \\
HSA & Human Serum Albumin \\
MMP & Mitochondrial Membrane Potential \\
MPT & Mitochondrial Permeability Transition \\
mPTP & Mitochondrial Permeability Transition Pore \\
MTT & 3-(4,5-dimethyl-2-thiazoyl)-2,5-diphenyltetrazolium \\
& bromide \\
NMR & Nuclear Magnetic Resonance \\
NADPH & Nicotinamide adenine dinucleotide phosphate \\
PBS & Phosphate Buffered Saline \\
PTA & 1,3,5-triaza-7-phosphaadamantane \\
ROS & Reactive Oxygen Species \\
& \\
\hline
\end{tabular}


RT

Trx

Room Temperature

TrxR Thioredoxin Reductase

UV Ultraviolet

VDAC Voltage-dependent Anion Channel

\section{Author's contribution}

Cristina Sánchez-de-Diego and Inés Mármol have contributed equally to this work.

\section{Acknowledgements}

This study was supported by the projects: the Ministry of Science and Innovation (FEDER CTQ2013-48635-C2-1-P and SAF2013-41651-R), funds from Aragon Regional Government (A-32 and E104) and CIBER (Centros de Investigación Biomédica en RED) Sub-progarm (CIBERobn, CB06/03/1012) by the Instituto de Salud Carlos III. Authors thank to Dr. Javier Godino of Centro de Investigación Biomédica de Aragón (CIBA), España for technical assistance: http://www.iacs.aragon.es.

\section{Appendix A. Supplementary data}

Supplementary data to this article can be found online at doi:10. 1016/j.jinorgbio.2016.11.009.

\section{References}

[1] R. Houlston, Mol. Pathol. 54 (2001) 206

[2] P.R. Holt, P. Kozuch, S. Mewar, Best Pract. Res. Clin. Gastroenterol. 23 (2009) 889-907.

[3] A. Bartnik, A.J. Nirmal, S.-Y. Yang, Vaccines 1 (2013) 1.

[4] N.H. Tran, L.L. Cavalcante, S.J. Lubner, D.L. Mulkerin, N.K. LoConte, L. Clipson, K.A. Matkowskyj, D.A. Deming, Ther. Adv. Med. Oncol. 7 (2015) 252-262.

[5] P. Ragnhammar, L. Hafström, P. Nygren, B. Glimelius, Acta Oncol. 40 (2000) 282-308.

[6] B. Rosenberg, L. Van Camp, T. Krigas, Nature 205 (1965) 698-699.

[7] B. Rosenberg, L. Vancamp, Nature 222 (1969) 385-386.

[8] K.R. Barnes, S.J. Lippard, Met. Ions Biol. Syst. 42 (2004) 143-177.

[9] A. Agarwal, J.z. Balla, J. Alam, A.J. Croatt, K.A. Nath, Kidney Int. 48 (1995) 1298-1307.

[10] N. Muhammad, Z. Guo, Curr. Opin. Chem. Biol. 19 (2014) 144-153.

[11] S. Komeda, A. Casini, Curr. Top. Med. Chem. 12 (2012) 219-235.

[12] G. Gasser, N. Metzler-Nolte, Curr. Opin. Chem. Biol. 16 (2012) 84-9

[13] N. Cutillas, G.S. Yellol, C. de Haro, C. Vicente, V. Rodríguez, J. Ruiz, Coord. Chem. Rev. 257 (2013) 2784-2797.

[14] C.G. Hartinger, N. Metzler-Nolte, P.J. Dyson, Organometallics 31 (2012) 5677-5685.

[15] S. Medici, M. Peana, V.M. Nurchi, J.I. Lachowicz, G. Crisponi, M.A. Zoroddu, Coord. Chem. Rev. 284 (2015) 329-350.

[16] C.-M. Che, R.W.-Y. Sun, Chem. Commun. 47 (2011) 9554-9560.

[17] L. Ronconi, D. Aldinucci, Q. Ping Dou, D. Fregona, Anti Cancer Agents Med. Chem. 10 (2010) 283-292.

[18] S. Nobili, E. Mini, I. Landini, C. Gabbiani, A. Casini, L. Messori, Med. Res. Rev. 30 (2010) 550-580.

[19] I. Ott, Coord. Chem. Rev. 253 (2009) 1670-1681.

[20] C. Nardon, G. Boscutti, D. Fregona, Anticancer Res. 34 (2014) 487-492.

[21] R.W.-Y. Sun, C.-M. Che, Coord. Chem. Rev. 253 (2009) 1682-1691.

[22] L. Oehninger, R. Rubbiani, I. Ott, Dalton Trans. 42 (2013) 3269-3284

[23] E. García-Moreno, S. Gascón, M.J. Rodriguez-Yoldi, E. Cerrada, M. Laguna, Organometallics 32 (2013) 3710-3720.

[24] E. Vergara, A. Casini, F. Sorrentino, O. Zava, E. Cerrada, M.P. Rigobello, A. Bindoli, M. Laguna, P.J. Dyson, ChemMedChem 5 (2010) 96-102.

[25] E. Vergara, E. Cerrada, A. Casini, O. Zava, M. Laguna, P.J. Dyson, Organometallics 29 (2010) 2596-2603.

[26] P. Bergamini, L. Marvelli, A. Marchi, F. Vassanelli, M. Fogagnolo, P. Formaglio, T. Bernardi, R. Gavioli, F. Sforza, Inorg. Chim. Acta 391 (2012) $162-170$.

[27] E. García-Moreno, S. Gascón, E. Atrián-Blasco, M.J. Rodriguez-Yoldi, E. Cerrada, M. Laguna, Eur. J. Med. Chem. 79 (2014) 164-172.
[28] E. Vergara, E. Cerrada, C. Clavel, A. Casini, M. Laguna, Dalton Trans. 40 (2011) 10927-10935.

[29] A. de Almeida, B.L. Oliveira, J.D.G. Correia, G. Soveral, A. Casini, Coord. Chem. Rev. 257 (2013) 2689-2704

[30] R.G. Pearson, J. Chem. Sci. 117 (2005) 369

[31] C.H. Lillig, A. Holmgren, Antioxid. Redox Signal. 9 (2007) 25-47.

[32] A. Bindoli, M.P. Rigobello, G. Scutari, C. Gabbiani, A. Casini, L. Messori, Coord. Chem. Rev. 253 (2009) 1692-1707.

[33] L. Engman, M. McNaughton, M. Gajewska, S. Kumar, A. Birmingham, G. Powis, Anti-Cancer Drugs 17 (2006) 539-544.

[34] M.-H. Yoo, X.-M. Xu, B.A. Carlson, V.N. Gladyshev, D.L. Hatfield, J. Biol. Chem. 281 (2006) 13005-13008.

[35] E.S.J. Arnér, H. Nakamura, T. Sasada, J. Yodoi, A. Holmgren, G. Spyrou, Free Radic. Biol. Med. 31 (2001) 1170-1178.

[36] S. Gromer, L.D. Arscott, C.H. Williams, R.H. Schirmer, K. Becker, J. Biol. Chem. 273 (1998) 20096-20101.

[37] J. van Meerloo, G.J.L. Kaspers, J. Cloos, Methods Mol. Biol. (Clifton, N.J.) 731 (2011) 237-245.

[38] M.E. Christensen, E.S. Jansen, W. Sanchez, N.J. Waterhouse, Methods 61 (2013) 138-145.

[39] M. Ruiz-Leal, S. George, Mar. Environ. Res. 58 (2004) 631-635.

[40] P.F. Smith, G.D. Hoke, D.W. Alberts, P.J. Bugelski, S. Lupo, C.K. Mirabelli, G.F. Rush, J. Pharmacol. Exp. Ther. 249 (1989) 944-950.

[41] G.D. Hoke, R.A. Macia, P.C. Meunier, P.J. Bugelski, C.K. Mirabelli, G.F. Rush, W.D. Matthews, Toxicol. Appl. Pharmacol. 100 (1989) 293-306.

[42] T. Kosa, T. Maruyama, M. Otagiri, Pharm. Res. 14 (1997) 1607-1612.

[43] G.J. Finlay, B.C. Baguley, Cancer Chemother. Pharmacol. 45 (2000) 417-422

[44] D.C. Carter, J.X. Ho, Adv. Protein Chem. 45 (1994) 153-203.

[45] N.S. Ryder, I. Frank, J. Med. Vet. Mycol. 30 (1992) 451-460

[46] X.M. He, D.C. Carter, Nature 358 (1992) 209-215.

[47] K. Yamasaki, T. Maruyama, U. Kragh-Hansen, M. Otagiri, Biochim. Biophys. Acta Protein Struct. Mol. Enzymol. 1295 (1996) 147-157.

[48] J.F. Neault, H.A. Tajmir-Riahi, Biochim. Biophys. Acta Protein Struct. Mol. Enzymol. 1384 (1998) 153-159.

[49] E. Garcia-Moreno, A. Tomas, E. Atrian-Blasco, S. Gascon, E. Romanos, M. Jesus Rodriguez-Yoldi, E. Cerrada, M. Laguna, Dalton Trans. 45 (2016) $2462-2475$

[50] A.J. Canumalla, S. Schraa, A.A. Isab, C.F. Shaw Iii, E. Gleichmann, L. Dunemann, M. Turfeld, J. Biol. Inorg. Chem. 3 (1998) 9-17.

[51] C.D. Sanghvi, P.M. Olsen, C. Elix, S.B. Peng, D. Wang, D.M. Shin, K.I. Hardcastle, C.E. MacBeth, J.F. Eichler, J. Inorg. Biochem. 128 (2013) 68-76

[52] L.R. Gouvea, L.S. Garcia, D.R. Lachter, P.R. Nunes, F.v. de Castro Pereira, E.n.P. Silveira-Lacerda, S.R.W. Louro, P.J.S. Barbeira, L.R. Teixeira, Eur. J. Med. Chem. 55 (2012) 67-73.

[53] N. Ji, C. Qiu, X. Li, L. Xiong, Q. Sun, Colloids Surf., B 128 (2015) 594-599.

[54] H.-L. Yue, Y.-J. Hu, J. Chen, A.-M. Bai, Y. Ouyang, Colloids Surf. B 122 (2014) 107-114

[55] Y. Zhang, S. Shi, X. Sun, X. Xiong, M. Peng, J. Inorg. Biochem. 105 (2011) $1529-1537$.

[56] J.R. Lakowicz, Principles of Fluorescence Spectroscopy, Springer, Baltimore, Maryland, USA, 2006.

[57] X.-X. Cheng, Y. Lui, B. Zhou, X.-H.X.a.Y. Liu, Spectrochim. Acta A (2009) 922-928.

[58] P.D. Ross, S. Subramanian, Biochemistry 20 (1981) 3096-3102.

[59] I.J. Hidalgo, T.J. Raub, R.T. Borchardt, Gastroenterology (1989) 736-749.

[60] J.C. Reed, Nat. Rev. Drug 1 (2002) 111-121.

[61] J. Yang, X. Liu, K. Bhalla, C.N. Kim, A.M. Ibrado, J. Cai, T.-I. Peng, D.P Jones, X. Wang, Science 275 (1997) 1129-1132.

[62] T. Kuwana, M.R. Mackey, G. Perkins, M.H. Ellisman, M. Latterich, R Schneiter, D.R. Green, D.D. Newmeyer, Cell 111 (2002) 331-342.

[63] H. Zou, Y. Li, X. Liu, X. Wang, J. Biol. Chem. 274 (1999) 11549-11556.

[64] P. Li, D. Nijhawan, I. Budihardjo, S.M. Srinivasula, M. Ahmad, E.S. Alnemri, X. Wang, Cell 91 (1997) 479-489.

[65] D. Ahmed, P. Eide, I. Eilertsen, S. Danielsen, M. Eknaes, M. Hektoen, G. Lind, R. Lothe, Oncogenesis 2 (2013), e71.

[66] M. Selvakumaran, H.-K. Lin, T. Miyashita, H.G. Wang, S. Krajewski, J.C. Reed, B. Hoffman, D. Liebermann, Oncogene 9 (1994) 1791-1798.

[67] S. Orrenius, B. Zhivotovsky, P. Nicotera, Nat. Rev. Mol. Cell Biol. 4 (2003) $552-565$.

[68] V. Gogvadze, S. Orrenius, B. Zhivotovsky, Biochim. Biophys. Acta Bioenerg. 1757 (2006) 639-647.

[69] S. Marchi, C. Giorgi, J.M. Suski, C. Agnoletto, A. Bononi, M. Bonora, E. De Marchi, S. Missiroli, S. Patergnani, F. Poletti, J. Signal Transduct. 2012 (2011).

[70] E. Gottlieb, S. Armour, M. Harris, C. Thompson, Cell Death Differ. 10 (2003) 709-717.

[71] S.J. Riedl, Y. Shi, Nat. Rev. Mol. Cell Biol. 5 (2004) 897-907.

[72] E.A. Slee, C. Adrain, S.J. Martin, J. Biol. Chem. 276 (2001) 7320-7326. 
[73] X. Li, G. Wang, J. Zhao, H. Ding, C. Cunningham, F. Chen, D. Flynn, E. Reed, Q. Li, Cell. Mol. Life Sci. 62 (2005) 894-904.

[74] D. Xiao, A. Herman-Antosiewicz, J. Antosiewicz, H. Xiao, M. Brisson, J.S. Lazo, S.V. Singh, Oncogene 24 (2005) 6256-6268.

[75] B.J. Pages, D.L. Ang, E.P. Wright, J.R. Aldrich-Wright, Dalton Trans. 44 (2015) 3505-3526.

[76] B.M. Zeglis, V.C. Pierre, J.K. Barton, Chem. Commun. (2007) 4565-4579.

[77] A. Casini, C. Gabbiani, F. Sorrentino, M.P. Rigobello, A. Bindoli, T.J. Geldbach, A. Marrone, N. Re, C.G. Hartinger, P.J. Dyson, J. Med. Chem. 51 (2008) 6773-6781.

[78] A. Casini, C. Hartinger, C. Gabbiani, E. Mini, P.J. Dyson, B.K. Keppler, L. Messori, J. Inorg. Biochem. 102 (2008) 564-575.

[79] K. WoŸniak, J. Błasiak, Acta Biochim. Pol. 49 (2002) 583-596.

[80] A. Saraste, K. Pulkki, Cardiovasc. Res. 45 (2000) 528-537.

[81] S.H.Z. Ariffin, W.Y. Wong, I.Z.Z. Abidin, R.M.A. Wahab, Z.Z. Ariffin, S. Senafi, BMC Complement. Altern. Med. 14 (2014) 508.

[82] A. Lawen, BioEssays 25 (2003) 888-896.

[83] A.A. Hostetter, M.F. Osborn, V.J. DeRose, Chem. Biol. 7 (2011) 218-225.

[84] M. Le Bras, M.V. Clement, S. Pervaiz, C. Brenner, Histol. Histopathol. 20 (2005) 205-220.

[85] X. Cheng, P. Holenya, S. Can, H. Alborzinia, R. Rubbiani, I. Ott, S. Wölfl, Mol. Cancer 13 (2014) 221-236.
[86] K. Księżakowska-Łakoma, M. Żyła, J.R. Wilczyński, Prz. Menopauzalny 13 (2014) 136.

[87] A. Acharya, I. Das, D. Chandhok, T. Saha, Oxidative Med. Cell. Longev. 3 (2010) 23-34.

[88] L. Zhong, E.S. Arnér, J. Ljung, F. Åslund, A. Holmgren, J. Biol. Chem. 273 (1998) 8581-8591.

[89] A. De Nisi, C. Bergamini, M. Leonzio, G. Sartor, R. Fato, M. Naldi, M. Monari, N. Calonghi, M. Bandini, Dalton Trans. 45 (2016) 1546-1553.

[90] V. Andermark, K. Goke, M. Kokoschka, M.A. Abu El Maaty, C.T. Lum, T. Zou, R.W.-Y. Sun, E. Aguilo, L. Oehninger, L. Rodriguez, H. Bunjes, S. Wolfl, C.-M. Che, I. Ott, J. Inorg. Biochem. 160 (2016) 140-148.

[91] D. Zhang, Z. Xu, J. Yuan, Y.-X. Zhao, Z.-Y. Qiao, Y.-J. Gao, G.-A. Yu, J. Li, H. Wang, J. Med. Chem. 57 (2014) 8132-8139.

[92] J. Arcau, V. Andermark, E. Aguilo, A. Gandioso, A. Moro, M. Cetina, J.C. Lima, K. Rissanen, I. Ott, L. Rodriguez, Dalton Trans. 43 (2014) 4426-4436.

[93] A. Meyer, C.P. Bagowski, M. Kokoschka, M. Stefanopoulou, H. Alborzinia, S Can, D.H. Vlecken, W.S. Sheldrick, S. Wolfl, I. Ott, Angew. Chem. Int. Ed. Eng. 51 (2012) 8895-8899.

[94] E.S.J. Arnér, Cell Implication of Redox Signalling, first ed., Imperial College Press, London, 2003.

[95] A.-K. Rundlöf, E.S. Arnér, Antioxid. Redox Signal. 6 (2004) 41-52. 